Boise State University

ScholarWorks

$12-1-2010$

\title{
A Comparison of Cumulative-Germination Response of Cheatgrass (Bromus tectorum L.) and Five Perennial Bunchgrass Species to Simulated Field-Temperature Regimes
}

Stuart P. Hardegree

Northwest Watershed Research Center

Corey A. Moffet

US Sheep Experiment Station

Bruce A. Roundy

Brigham Young University - Utah

Thomas A. Jones

Utah State University

Stephen J. Novak

Boise State University

See next page for additional authors

\section{(c) $98 \%$}

This is an author-produced, peer-reviewed version of this article. (C) 2009, Elsevier. Licensed under the Creative Commons AttributionNonCommercial-NoDerivatives 4.0 International License (https://creativecommons.org/licenses/by-nc-nd/4.0/). The final, definitive version of this document can be found online at Environmental and Experimental Botany, doi: 10.1016/j.envexpbot.2010.04.012 
Authors

Stuart P. Hardegree, Corey A. Moffet, Bruce A. Roundy, Thomas A. Jones, Stephen J. Novak, Patrick E. Clark, Frederick B. Pierson, and Gerald N. Flerchinger 


\title{
A Comparison of Cumulative-Germination Response of Cheatgrass (Bromus tectorum L.) and Five Perennial Bunchgrass Species to Simulated Field-Temperature Regimes
}

\author{
Stuart P. Hardegree \\ USDA-Agricultural Research Service, Northwest \\ Watershed Research Center \\ Corey A. Moffet \\ USDA-Agricultural Research Service, US Sheep \\ Experiment Station \\ Bruce A. Roundy \\ Brigham Young University \\ Thomas A. Jones \\ USDA-ARS Forage and Range Research Laboratory
}

\author{
Stephen J. Novak \\ Boise State University \\ Patrick E. Clark \\ USDA-Agricultural Research Service, Northwest \\ Watershed Research Center \\ Frederick B. Pierson \\ USDA-Agricultural Research Service, Northwest \\ Watershed Research Center \\ Gerald N. Flerchinger \\ USDA-Agricultural Research Service, Northwest \\ Watershed Research Center
}

\begin{abstract}
Cheatgrass (Bromus tectorum L.) has come to dominate millions of hectares of rangeland in the Intermountain western United States. Previous studies have hypothesized that one mechanism conferring a competitive advantage to this species is the ability to germinate rapidly at low temperatures in the fall, winter and spring and, therefore, initiate growth and establishment more rapidly than more desirable perennial bunchgrass species. In this experiment, we developed thermal-germination-response models for multiple seedlots of cheatgrass and five perennial grass species. We conducted sensitivity analysis on potentialcumulative-germination response to a 38-y simulation of field-variable conditions of seedbed temperature and moisture. Cheatgrass uniformly germinated at a higher rate, and required significantly less time to complete germination than any of the perennial species for all but the slowest seed subpopulations. A germination-rate-sum index was used to integrate relative response characteristics over time. This index showed that germination rate of the most rapidly germinating subpopulations of cheatgrass were 2-5 times higher than for the other species tested. Model simulations of this type provide a more ecologically relevant basis for seedlot evaluation as they allow comparisons across a wide range of potential conditions that may be experienced in the field.
\end{abstract}

Keywords: seed, germination, temperature, model, bottlebrush squirreltail, big squirreltail, bluebunch wheatgrass, basin wildrye, cheatgrass, sandberg bluegrass

\section{Introduction}

Cheatgrass (Bromus tectorum L.) now dominates millions of hectares of sagebrush-bunchgrass rangeland in the Intermountain region of the western United States (Mack 1981; Young et al. 1987; D'Antonio and Vitousek 1992; Knapp 1996; DiTomaso 2000). It has been suggested that rapid germination, particularly at low temperatures in the late fall, winter and early spring, may contribute to the competitive success of this species (Hull 1964; Harris 1967; Harris and Wilson 1970; Wilson et al. 1974; Harris 1977; Thill et al. 1979; Hardegree 1994a,b; Beckstead et al. 1996; Goodwin et al. 1996; Hardegree et al. 2003). Young and Evans (1982) evaluated thermal response of a large number of seedlots of cheatgrass and other species, under a wide variety of thermal conditions, but only reported temperature effects on total germination percentage. Several previous studies have evaluated thermal or hydrothermal-germination response of cheatgrass and other rangeland grasses, but limited analysis to comparison of model indices, or focused on seed-dormancy processes (Wester 1991; Jordan and Haferkamp 1989; Hardegree 1994a,b; Romo and Eddleman 1995; Allen et al. 2000; Meyer et al., 2000). Hardegree and Van Vactor (2000) and Hardegree et al. (2003) proposed that model estimates of cumulative germination response to potential field-variable temperature and moisture regimes might provide a more ecologically relevant index for species and seedlot 
NOTICE: This is the author's version of a work accepted for publication by Elsevier. Changes resulting from the publishing process, including peer review, editing, corrections, structural formatting and other quality control mechanisms, may not be reflected in this document. Changes may have been made to this work since it was submitted for publication. The definitive version has been published in Environmental and Experimental Botany, 69(3), 2010. DOI: 10.1016/j.envexpbot.2010.04.012

comparisons. Hardegree et al. (2008) evaluated thermal-germination response of 41 accessions of bottlebrush squirreltail [Elymus elymoides (Raf.) Swezey] and big squirreltail [Elymus multisetus (J.G. Smith) Burtt-Davy] using this methodology and Roundy et al. (2007) used a similar approach to evaluate potential germination response of 18 cheatgrass seedlots over a four-year period at nine big sagebrush (Artemisia tridentata Nutt.) sites in Nevada and Utah. Historical simulation of potential germination response can be used to rank seedlots, but also provides sensitivity analysis on the effects of annual and seasonal variability in temperature and water conditions that may be experienced in the field (Hardegree 2006b).

The purpose of the current study was to expand upon previous analyses of Hardegree et al. (2003), Roundy et al. (2007) and Hardegree et al. (2008) to include multiple accessions of cheatgrass, big and bottlebrush squirreltail, bluebunch wheatgrass [Pseudoroegneria spicata (Pursh) Löve], basin wildrye [Leymus cinereus (Scribn. and Merr.) A. Löve] and Sandberg bluegrass (Poa secunda Vasey). Specific objectives were to compare simulated germination rate of cheatgrass and perennial-bunchgrass species under historical field-temperature regimes; and to evaluate potential variability in cumulative germination response as a function of seasonal and annual variability in seedbed temperature and moisture.

\section{Methods}

Thermal germination-response data for 23 seedlots of bottlebrush squirreltail, 20 seedlots of big squirreltail, eight seedlots of cheatgrass, three seedlots of bluebunch wheatgrass, and one seedlot of Sandberg bluegrass, were derived from several previous studies as described by Hardegree et al. (2003), Hardegree (2006a), Roundy et al. (2007) and Hardegree et al. (2008).

Five additional seedlots of bluebunch wheatgrass; five seedlots of basin wildrye, four seedlots of bottlebrush squirreltail and one seedlot of big squirreltail were harvested from nursery-grown plants at the Utah State University, Evans Farm, Millville, UT in 1996 for germination testing in 1997. The cultural practices for seed production followed similar procedures described by Jones et al. (2003) for big and bottlebrush squirreltail. The five seedlots of basin wildrye originated from two released varieties (Trailhead and Magnar) and three wildland collections (Benson, UT; Soda Springs, ID; Delcio, NV). The additional seedlots of bluebunch wheatgrass also originated from two released varieties (Whitmar and Goldar) and three wildland collections (Ainsworth BC, Connell, WA, and Meeker, CO). The four additional accessions of bottlebrush squirreltail and one accession of big squirreltail were derived from wildland collections (E. elymoides ssp. brevifolius from Buford, CO, Pueblo, CO and Los Lunas, NM; E. elymoides ssp. elymoides from Ten Sleep, WY; E. multisetus from Sand Hollow, ID). The three E. elymoides ssp. brevifolius accessions belonged to Group A as identified by Jones et al. (2003) and Hardegree et al. (2008). The Ainsworth BC collection of bluebunch wheatgrass, and Sand Hollow, ID collection of bottlebrush squirreltail, were the same as two previous accessions included from the previous study by Hardegree et al. (2003).

Twenty-one constant-temperature regimes between 3 and $38^{\circ} \mathrm{C}$ were tested for the 15 additional seedlots using a similar experimental design described by Hardegree (2006a). Germination vials, containing 30 seeds each, were replicated 5 times within each environmental chamber but individual temperature regimes were not replicated. Seeds were monitored every day, for up to 52 days in some of the colder temperature treatments, and were counted and removed when they exhibited radicle extension of $\geq 2 \mathrm{~mm}$.

One additional seedlot of Sandberg bluegrass was obtained from a commercial seed company and evaluated for thermal-germination response in 2007 using the same general experimental design described by Roundy et al. (2007) for cheatgrass seedlots, except that germination vials were replicated 4 times within each chamber.

The statistical-gridding (SG) procedure developed by Hardegree and Winstral (2006) and tested by Hardegree (2006b) was used to model germination rate (d-1) for each seedlot as a function of temperature and seedsubpopulation. Germination-rates as a function of temperature for all subpopulations (5-95\% in 5\% increments) of each seedlot were estim ated for each hour of a 255-d period between 6-Oct and 18-Jun of a given hydrologic year for a 38-year seedbed-microclimatic simulation as previously described by Hardegree et al. (2003). This process was repeated for all hours of the test period regardless of simulated soil-water potential (Flerchinger and Hardegree 2004) as described by Hardegree et al. (2008). Under a second scenario, germination rates were estimated only for hours in which water potential was estimated to be less negative than -1.0 MPa (Hardegree et al. 2003; Roundy et al. 2007). These hourly-rate estimates reflect the percentage progress toward germination of a given subpopulation during each hour. The summation of hourly-rate values over a 24-hour period, therefore, represents the percentage 
NOTICE: This is the author's version of a work accepted for publication by Elsevier. Changes resulting from the publishing process, including peer review, editing, corrections, structural formatting and other quality control mechanisms, may not be reflected in this document. Changes may have been made to this work since it was submitted for publication. The definitive version has been published in Environmental and Experimental Botany, 69(3), 2010. DOI: 10.1016/j.envexpbot.2010.04.012

progress toward germination for a given day, therefore, germination time can be estimated as the time it takes for the cumulative-germination- rate sum to become equal to 1 (Roundy and Biedenbender 1996; Phelps and Finch-Savage 1997; Hardegree et al. 1999).

Germination-rate sums were calculated for each combination of species, accession, seedlot-collection year, and subpopulation for every day of the 255-day simulation period for each year. Germination time was also calculated for every subpopulation for 12 simulated planting dates in each year starting on Oct-9 and every 21-days thereafter until 28-May. The last 8 simulated planting dates in this study were identical to those described by Hardegree et al. (2008) for 41 squirreltail seedlots. Rate-sums and germination-times were averaged across seedlot accessions that were collected in different years, and then averaged across all years of the test period by Julian date. Mean rate sums for a given Julian date and seedlot-accession were then averaged by species for cheatgrass, bluebunch wheatgrass, basin wildrye, Sandberg bluegrass, and big squirreltail; and by subspecies grouping for bottlebrush squirreltail (ssp. brevifolius Group A; ssp. brevifolius Group B; ssp. brevifolius Group C; ssp. elymoides) as identified by Jones et al. (2003) and Hardegree et al. (2008). The 5 seedlots of basin wildrye exhibited two distinct groupings based on relative population response and were divided into two categories: released varieties (Trailhead and Magnar) and wildland collections (Benson, UT; Soda Springs, ID; Delcio, NV).

Species and subspecies seedlot-groupings were compared for relative germination response using mixed-model Analysis of Variance (ANOVA) for: comparison of daily-rate sums on the 12 simulated planting dates; comparison of annual rate-sums accumulated over the entire 255-d evaluation period; and comparison of germination time as a function of simulated planting date for model simulations using all hourly temperatures, and for model simulations in which thermal-accumulation was only calculated when simulated soil water potential was less negative than -1.0 MPa. Daily and annual-rate sums, and germination-time values were only evaluated for select subpopulations (10\%, $30 \%, 50 \%$ and 70\%). The Fisher's protected least-square-difference test was used for multiple comparisons of significant main-treatment effects.

\section{Results}

The seasonal distribution of daily-germination rate-sums, as affected by temperature only, is shown in Figure 1. The vertical lines in this figure correspond to the 12 simulated planting dates. Species and subspecies groupings were roughly ranked based on maximum-daily rate-sum of the $50 \%$ subpopulation in the following order of relative germination rate (high to low): cheatgrass $>$ bluebunch wheatgrass, big squirreltail > bottlebrush squirreltail ssp. brevifolius Group $\mathrm{C}>$ bottlebrush squirreltail ssp. brevifolius Groups A,B; bottlebrush squirreltial ssp. elymoides $>$ Sandberg bluegrass $>$ basin wildrye (wildand collections) $>$ basin wildrye (released varieties). The results of the multiple-comparison test for significant differences among species groupings is shown in Table 1 for the $30 \%$ subpopulation for selected planting dates. Significant differences in daily rate-sums were dependent upon both planting date and subpopulation. Results of significance testing for other subpopulations and planting dates can be reviewed on-line at: http://... . Data for subpopulation variability in daily thermal-rate summation shows a consistent and expected pattern of seasonal variability across all species. Daily-germination rate-sum estimates were reduced by approximately $2 / 3$ when thermal accumulation was limited to periods when water potential was estimated to be less negative than -1.0 MPa (Fig. 2), but relative seedlot response and differences among seedlots was similar (Table $2 ;$ http://...).

The mean annual-cumulative-rate-sum as a function of seed subpopulation during the 255-d test period is shown for all seedlot groups in Figure 3. The cumulative rate-sum shown in this figure integrates the data in Fig. 1 to provide a more concise index for comparison of species and seedlot differences. As with the daily-rate-sum data, significance of species and seedlot differences were subpopulation dependant (Table 3; http://.. ). In general, Cheatgrass germination rates were 2-5 times higher than for the other species for the most rapidly germinating subpopulations, but were similar for all species for slower-germinating seed subpopulations (Figs. 1, 2, 3). An alternative way to interpret the data in Fig. 3 is to consider that the numerical value of the cumulative-rate-sum is equivalent to the number of times a given subpopulation would be expected to germinate if planted sequentially, immediately after germination occurred from the previous planting event. The data in Figure 3 overestimate the number of periods in which germination would be expected to occur as they do not take into account water-potential effects. The equivalent data for thermal accumulation above the $-1.0 \mathrm{MPa}$ water-potential threshold were of the same relative magnitude, but approximately $1 / 3$ the magnitude of the values for the data shown in Fig. 3 (Data not shown). 
NOTICE: This is the author's version of a work accepted for publication by Elsevier. Changes resulting from the publishing process, including peer review, editing, corrections, structural formatting and other quality control mechanisms, may not be reflected in this document. Changes may have been made to this work since it was submitted for publication. The definitive version has been published in Environmental and Experimental Botany, 69(3), 2010. DOI: 10.1016/j.envexpbot.2010.04.012

Patterns of cumulative germination matched the rate-sum data but differences in seedlot groupings were highly dependant on planting date (Figure 4, Table 4; http://... ). Simulated germination times for the 50\%-seed subpopulation ranged from about 50-100 days for most seedlot groupings for simulated planting dates in early December, to only 3-10 days in late May (Fig. 4a). Simulated germination times were greatly delayed when thermal accumulation was restricted to periods of relative water availability (Fig. 4b). This delay was relatively greater during warmer planting periods when the seeds were more likely to experience water stress.

\section{Discussion}

Wester (1991) summarized the results of many previous studies investigating temperature and water-stress effects on rangeland-plant germination. The majority of these studies evaluated only a limited number of static treatment effects, and did not address species-level variability in germination response. Young and Evans (1981; 1982), Evans and Young (1983), Evans et al. (1977), and Young et al. (1981; 2003), measured germination response of a large number of rangeland grass species to a wide range of constant and alternating-temperature regimes, but reported only total germination response. Young and Evans (1977) and Kitchen and Monsen (1994) reported thermal effects on rate as well as total germination percentage of squirreltail and bluebunch wheatgrass, respectively, but used a rate index that is confounded by differences in germination percentage (Scott et al. 1984; Brown and Mayer 1988). Thermal and hydrothermal models have been used to generate rate indices integrating potential response over a wide range of environmental conditions but most previous comparisons for rangeland species have been limited to simple ranking of thermal or hydrothermal coefficients (Jordan and Haferkamp 1989; Allen et al. 2000; Meyer et al. 2000). Hardegree and Van Vactor (2000) and Hardegree et al. (2003) suggested that thermal and hydrothermal germination models could be used in conjunction with measured or simulated microclimatic data to develop a more ecologically relevant basis for seedlot and species comparisons. Hardegree et al. (2003) and Hardegree (2006b) used this approach to simulate germination response to historical conditions of seedbed moisture and temperature, but only for one or two seedlots of a given species. Roundy et al. (2007) evaluated potential germination response to fieldvariable microclimatic conditions but limited analysis to evaluation of single species. Hardegree et al. (2008) is the only study of this type that has compared more than two seedlots of different species (big and bottlebrush squirreltail). The current study included re-analysis of these previous studies (Hardegree et al. 2003; Hardegree 2006b; Roundy et al. 2007; Hardegree et al. 2008) but expanded the comparison to include an expanded range of simulated planting dates, and new data for additional species and seedlots. The current study also included consideration of a water-potential threshold for thermal accumulation as discussed by Hardegree et al. (2003) and Roundy et al. (2008).

The results in this study confirm previous assertions that cheatgrass exhibits superior germination response to many perennial grass species, especially under conditions of low temperature in the late fall, winter and early spring (Hull 1964; Harris 1967; Harris and Wilson 1970; Wilson et al. 1974; Harris 1977; Thill et al. 1979; Hardegree 1994a,b; Beckstead et al. 1996; Goodwin et al. 1996; Hardegree et al. 2003). Our model simulations predicted relatively similar germination rates during the coolest part of the year (Figs. 1,2). Small germination-rate differences, however, are magnified when the inverse of rate is calculated to estimate actual germination time (Fig. 4), a more relevant basis for comparison of potential field performance (Arnold, 1959).

Several assumptions were made in this analysis that could affect interpretation of the simulated germination response. Assumptions inherent in thermal-germination models per se are thoroughly discussed by Hardegree et al. (1999). These assumptions were minimized for the statistical-gridding model used in the current experiment as developed and tested by Hardegree (2006a,b) and Hardegree and Winstral (2006). Additional assumptions were made in the application of the water-potential threshold concept first applied in a modeling context by Roundy et al. (2007). Hardegree et al. (2003) assessed the relative importance of different water-potential thresholds, however, and Roundy et al. (2007) confirmed that a threshold of -1.0 MPa would be expected to explain the majority of periods during which wet-thermal accumulation toward germination would be expected to occur. Additional studies should be conducted to confirm this methodology with additional species and seedlots using hydrothermal germination-response data.

Many important biotic and abiotic factors that affect germination response and subsequent emergence, growth and establishment in the field were also ignored in this analysis (Hegarty 1973; Egli and Tekrony 1996; Weaich et al. 1996; Beckstead et al. 2007). More rapid germination of cheatgrass is also only one component of a competitive syndrome that includes rapid root and shoot growth (Hull 1963; Harris 1967; Harris 1977; Link et al. 1990; Svejcar 1990; Aguirre and Johnson 1991; Nasri and Doescher 1995; Arredondo and Johnson 1998; Arredondo et al. 1998), 
NOTICE: This is the author's version of a work accepted for publication by Elsevier. Changes resulting from the publishing process, including peer review, editing, corrections, structural formatting and other quality control mechanisms, may not be reflected in this document. Changes may have been made to this work since it was submitted for publication. The definitive version has been published in Environmental and Experimental Botany, 69(3), 2010. DOI: 10.1016/j.envexpbot.2010.04.012

high seed production (Young et al. 1969; Humphrey and Schupp 2001; Hempy-Mayer and Pyke 2008), resource exclusion through efficient water utilization, especially in the upper soil layers (Evans et al. 1970; Cline et al. 1977; Melgoza et al. 1990; Booth et al. 2003a; Humphrey and Schupp 2004), alteration of the fire cycle (Whisenant 1990; Knapp 1996), and changes in nitrogen dynamics (Evans et al. 2001; Booth et al. 2003b; Rimer and Evans 2006). We believe, however, that this modeling approach yields a much higher level of ecologically relevant information than previous methods, and that this information could be used to identify relevant germination syndromes (Angevine and Chabot 1979; Humphrey and Schupp 1999) rather than merely ranking relative species response.

\section{Management Implications}

Methodologies discussed in this study provide a more ecologically relevant basis for comparison of thermal and water-potential effects on seed-germination response than previous approaches. Assessment of potential germination response to a wide number of potential field conditions expands relevant comparisons of species and seedlots to specifically include consideration of the impacts of highly stochastic weather and climate variables as moderated by the seedbed. Future utilization of these techniques could lead to classification of hydrothermal-germination syndromes but could also be used to develop a system for ranking sites and years based on relative favorability of seedbed microclimate. This type of tool would greatly assist in the interpretation of alternative seeding treatments and in quantification of climatic influences on establishment success. Methodology for evaluating weather and climate impacts on establishment success would also provide a basis for interpreting potential climate-change impacts on the stability of current plant communities. 
Aguirre, L., and D. A. Johnson. 1991. Influence of temperature and cheatgrass competition on seedling development of two bunchgrasses. Journal of Range Management 44:347-354.

Allen, P. S., S. E. Meyer, and M. A. Khan. 2000. Hydrothermal time as a tool in comparative germination studies. In: M. Black, K. J. Bradford, and K. J. Vasquez-Ramos [EDS.]. Seed biology: Advances and applications. CAB International, Wallingford, Oxon. p. 401-410.

Angevine, M. W., and B. F. Chabot. 1979. Seed germination syndromes in higher plants. In: O. T. Solbrig, S. Jain, G. B. Johnson, and P. H. Raven [EDS.]. Topics in plant population biology. Columbia University Press, New York. p. 188-206.

Arnold, C. Y. 1959. The determination and significance of the base temperature in a linear heat unit system. Journal of the American Society for Horticultural Science 74:430-445.

Arredondo, J. T., and D. A. Johnson. 1998. Clipping effects on root architecture and morphology of 3 range grasses. Journal of Range Management 51:207-213.

Arredondo, J. T., T. A. Jones, and D. A. Johnson. 1998. Seedling growth of Intermountain perennial and weedy annual grasses. Journal of Range Management 51:584-589.

Beckstead, J., S. E. Meyer, and P. S. Allen. 1996. Bromus tectorum seed germination: Between-population and between-year variation. Canadian Journal of Botany 74:875-882.

Beckstead, J., S. E. Meyer, C. J. Molder, and C. Smith. 2007. A race for survival: Can Bromus tectorum seeds escape Pyrenophora semeniperda-caused mortality by germinating quickly? Annals of Botany 99:907-914.

Booth, M. S., M. M. Caldwell, and J. M. Stark. 2003a. Overlapping resource use in three Great Basin species: Implications for community invasibility and vegetation dynamics. Journal of Ecology 91:36-48.

Booth, M. S., J. M. Stark, and M. M. Caldwell. 2003b. Inorganic N turnover and availability in annual- and perennial-dominated soils in a northern Utah shrub-steppe ecosystem. Biogeochemistry 66:311-330.

Brown, R. F., and D. G. Mayer. 1988. Representing cumulative germination. 1. Germination indices. Annals of Botany 61:117-125.

Cline, J. F., D. W. Uresk, and W. H. Rickard. 1977. Comparison of soil water used by a sagebrush-bunchgrass and a cheatgrass community. Journal of Range Management 30:199-201. 
D’Antonio, C. M., and P. M. Vitousek. 1992. Biological invasions by exotic grasses, the grass/fire cycle, and global change. Annual Review of Ecology and Systematics 23:63-87.

DiTomaso, J. M. 2000. Invasive weeds in rangelands: Species, impacts, and management. Weed Science 48:255265.

Egli, D. B., and D. M. TeKrony. 1996. Seedbed conditions and prediction of field emergence of soybean seed. Journal of Production Agriculture 9:365-370.

Evans, R. A., H. R. Holbro, R. E. Eckert, and J. A. Young. 1970. Functional environment of downy brome communities in relation to weed control and revegetation. Weed Science 18:154-162.

Evans, R. A., J. A. Young, and B. A. Roundy. 1977. Seedbed requirements for germination of sandberg bluegrass. Agronomy Journal 69:817-820.

Evans, R. A., and J. A. Young. 1983. 'Magnar' basin wildrye-germination in relation to temperature. Journal of Range Management 36:395-398.

Evans, R. D., R. Rimer, L. Sperry, and J. Belnap. 2001. Exotic plant invasion alters nitrogen dynamics in an arid grassland. Ecological Applications 11:1301-1310.

Flerchinger, G. N. and S. P. Hardegree. 2004. Modeling near-surface soil temperature and moisture for germination response predictions of post-wildfire seedbeds. Journal of Arid Environments 59:369-385.

Goodwin, J. R., P. S. Doescher, and L. E. Eddleman. 1996. Germination of Idaho fescue and cheatgrass seeds from coexisting populations. Northwest Science 70:230-241.

Hardegree, S. P., and S. S. Van Vactor. 2000. Germination and emergence of primed grass seeds under field and simulated-field temperature regimes. Annals of Botany 85:379-390.

Hardegree, S. P., G. N. Flerchinger, and S. S. Van Vactor. 2003. Hydrothermal germination response and the development of probabilistic germination profiles. Ecological Modelling 167:305-322.

Hardegree, S. P., T. A. Jones, F. B. Pierson, P. E. Clark, and G. N. Flerchinger. 2008. Dynamic variability in thermal-germination response of squirreltail (Elymus elymoides and Elymus multisetus). Environmental and Experimental Botany 62:120-128.

Hardegree, S. P., S. S. Van Vactor, F. B. Pierson, and D. E. Palmquist. 1999. Predicting variable-temperature response of non-dormant seeds from constant-temperature germination data. Journal of Range Management 52:83-91. 
Hardegree, S. P. 2006a. Predicting germination response to temperature. I. Cardinal-temperature models and subpopulation-specific regression. Annals of Botany 97:1115-1125.

Hardegree, S. P. 2006b. Predicting germination response to temperature. III. Model validation under field-variable temperature conditions. Annals of Botany 98:827- 834.

Hardegree, S. P. and A. H. Winstral. 2006. Predicting germination response to temperature. II. Three-dimensional regression, statistical gridding and iterative-probit optimization using measured and interpolatedsubpopulation data. Annals of Botany 98:403-410.

Hardegree, S. P. 1994a. Matric priming increases germination rate of Great Basin native perennial grasses. Agronomy Journal 86:289-293.

Hardegree, S. P. 1994b. Drying and storage effects on germination of primed grass seeds. Journal of Range Management 47:196-199.

Harris, G. A. 1967. Some competitive relationships between Agropyron spicatum and Bromus tectorum. Ecological Monographs 37:89-111.

Harris, G. A. 1977. Root phenology as a factor of competition among grass seedlings. Journal of Range Management 30:172-177.

Harris, G. A., and A. M. Wilson. 1970. Competition for moisture among seedlings of annual and perennial grasses as influenced by root elongation at low temperature. Ecology 51:530-534.

Hegarty, T. W. 1973. Temperature relations of germination in the field. In: W. Heydecker [ED.]. Seed Ecology. Butterworths, London. p. 411-432.

Hempy-Mayer, K. and D. A. Pyke. Defoliation effects on Bromus tectorum seed production: Implications for grazing. Rangeland Ecology and Management 61:116-123.

Hull, A. C. 1963. Competition and water requirements of cheatgrass and wheatgrasses in the greenhouse. Journal of Range Management 16:199-204.

Hull, A. C. 1964. Emergence of cheatgrass and three wheatgrasses from four seeding depths. Journal of Range Management 17:32-35.

Humphrey, L. D., and E. W. Schupp. 2001. Seed banks of Bromus tectorum-dominated communities in the Great Basin. Western North American Naturalist 61:85-92. 
NOTICE: This is the author's version of a work accepted for publication by Elsevier. Changes resulting from the publishing process, including peer review, editing, corrections, structural formatting and other quality control mechanisms, may not be reflected in this document. Changes may have been made to this work since it was submitted for publication. The definitive version has been published in Environmental and Experimental Botany, 69(3), 2010. DOI: 10.1016/j.envexpbot.2010.04.012

Humphrey, L. D., and E. W. Schupp. 1999. Temporal patterns of seedling emergence and early survival of Great Basin perennial plant species. Great Basin Naturalist 59:35-49.

Humphrey, L. D. and E. W. Schupp. 2004. Competition as a barrier to establishment of a native perennial grass (Elymus elymoides) in alien annual grass (Bromus tectorum) communities. Journal of Arid Environments $58: 405-422$.

Jones, T. A., D. C. Nelson, J. T. Arredondo, and M. G. Redinbaugh. 2003. Characterization of diversity among 3 squirreltail taxa. Journal of Range Management 56:474-482.

Jordan, G. L. and M. R. Haferkamp. 1989. Temperature responses and calculated heat units for germination of several range grasses and shrubs. Journal of Range Management 42:41-45.

Kitchen, S. G. and S. B. Monsen. 1994. Germination rate and emergence success in bluebunch wheatgrass. Journal of Range Management 47:145-150.

Knapp, P. A. 1996. Cheatgrass (Bromus tectorum L.) dominance in the Great Basin desert - history, persistence, and influences to human activities. Global Environmental Change, Human and Policy Dimensions 6:37-52.

Link, S. O., G. W. Gee, and J. F. Downs. 1990. The effect of water stress on phenological and ecophysiological characteristics of cheatgrass and Sandberg's bluegrass. Journal of Range Management 43:506-513.

Mack, R. N. 1981. Invasion of Bromus tectorum L. into western North America: an ecological chronicle. Agroecosystems 7:145-165.

Melgoza, G., R. S. Nowak, and R. J. Tausch. 1990. Soil water exploitation after fire: competition between Bromus tectorum (cheatgrass) and two native species. Oecologia 83:7-13.

Meyer, S. E., S. B. Debaene-Gill, and P. S. Allen. 2000. Using hydrothermal time concepts to model seed germination response to temperature, dormancy loss and priming effects in Elymus elymoides. Seed Science Research 10:213-223.

Nasri, M. and P. S. Doescher. 1995. Effect of temperature on growth of cheatgrass and Idaho fescue. Journal of Range Management 48:406-409.

Phelps, K., and W. E. Finch-Savage. 1997. A statistical perspective on threshold type germination models. In: R. H. Ellis, M. Black, A. J. Murdoch, and T. D. Hong [EDS.]. Basic and applied aspects of seed biology. Kluwer Academic Publishers, Dordrecht. p. 361-368. 
Rimer, R. L., and R. D. Evans. 2006. Invasion of downy brome (Bromus tectorum L.) causes rapid changes in the nitrogen cycle. American Midland Naturalist 156:252-258.

Romo, J. T., and L. E. Eddleman. 1995. Use of degree-days in multiple-temperature experiments. Journal of Range Management 48:410-416.

Roundy, B. A., S. P. Hardegree, J. C. Chambers, and A. Whittaker. 2007. Prediction of cheatgrass field germination potential using wet thermal accumulation. Rangeland Ecology and Management 60:613-623.

Roundy, B. A., and S. H. Biedenbender. 1996. Germination of warm-season grasses under constant and dynamic temperatures. Journal of Range Management 49:425-431.

Scott, S. J., R. A. Jones, and W. A. Williams. 1984. Review of data analysis methods for seed germination. Crop Science 24:1192-1199.

Svejcar, T. 1990. Root length, leaf area, and biomass of crested wheatgrass and cheatgrass seedlings. Journal of Range Management 43:446-448.

Thill, D. C., R. D. Schirmann, and A. P. Appleby. 1979. Influence of soil moisture, temperature, and compaction on the germination of downy brome (Bromus tectorum). Weed Science 27:625-630.

Weaich, K., K. L. Bristow, and A. Cass. 1996. Simulating maize emergence using soil and climate data. Agronomy Journal 88:667-674.

Wester, D.B. 1991. A summary of range plant seed germination research. International Center for Arid and Semiarid Land Studies (ICASALS) no. 91-12.

Whisenant, S. G. 1990. Changing fire frequencies on Idaho's Snake River Plains: ecological and management implications. In: E. D. McArthur, E. M. Romney, S. D. Smith and P. T. Tueller [COMPILERS]. Proceedings - Symposium on cheatgrass invasion, shrub die-off and other aspects of shrub biology and management, 5-7 April, 1989. Ogden, UT: USDA Forest Service Intermountain Research Station General Technical Report INT-276. p. 4-10.

Wilson, A. M., D. E. Wonderchek, and C. J. Goebel. 1974. Responses of range grass seeds to winter environments. Journal of Range Management 27:120-122.

Young, J. A., and R. A. Evans. 1982. Temperature profiles for germination of cool season range grasses. USDA, ARS, ARR-W-27, Oakland, CA. 92 p.

Young, J. A., and R. A. Evans. 1977. Squirreltail seed germination. Journal of Range Management 30:33-36. 
NOTICE: This is the author's version of a work accepted for publication by Elsevier. Changes resulting from the publishing process, including peer review, editing, corrections, structural formatting and other quality control mechanisms, may not be reflected in this document. Changes may have been made to this work since it was submitted for publication. The definitive version has been published in Environmental and Experimental Botany, 69(3), 2010. DOI: 10.1016/j.envexpbot.2010.04.012

Young, J. A., and R. A. Evans. 1981. Germination of Great Basin wildrye seeds collected from native stands.

Agronomy Journal 73:917-920.

Young, J. A., R. E. Eckert, and R. A. Evans. 1981. Temperature profiles for germination of bluebunch and beardless wheatgrasses. Journal of Range Management 34:84-89.

Young, J. A., C. D. Clements, and T. Jones. 2003. Germination of seeds of big and bottlebrush squirreltail. Journal of Range Management 56:277-281.

Young, J. A., R. A. Evans, and R. E. Eckert. 1969. Population dynamics of downy brome. Weed Science 17:20-26.

Young, J. A., R. A. Evans, R. E. Eckert and B. L. Kay. 1987. Cheatgrass. Rangelands 9:266-270. 


\section{FIGURES}

Figure 1. Seasonal variability in mean daily-rate-sum as a function of seed subpopulation and seedlot group for Bromus tectorum (^), Elymus multisetus ( $\diamond)$, Pseudoroegneria spicata ( $\nabla)$, Elymus elymoides ssp. brevifolius Group C ( $)$, Elymus elymoides ssp. brevifolius Group B ( $\square$ ), Elymus elymoides ssp. elymoides ( $\Delta$ ), Elymus elymoides ssp. brevifolius Group A (০), Leymus cinereus wildland collections (closed octagon), Poa secunda ( $\downarrow$ ), and Leymus cinereus released varieties ( sum means were derived by first averaging by seedlot across all years, and then across seedlots within groups. Rate-sum means in this figure were calculated for all hours regardless of water potential estimate. Vertical lines on x-axis represent simulated planting dates.

Figure 2. Seasonal variability in mean daily-rate-sum as a function of seed subpopulation and seedlot group for Bromus tectorum (^), Elymus multisetus ( $\diamond)$, Pseudoroegneria spicata ( $\nabla)$, Elymus elymoides ssp. brevifolius Group C ( $)$, Elymus elymoides ssp. brevifolius Group B ( $\square$ ), Elymus elymoides ssp. elymoides ( $\triangle$ ), Elymus elymoides ssp. brevifolius Group A (০), Leymus cinereus wildland collections (closed octagon), Poa secunda ( $\downarrow$ ), and Leymus cinereus released varieties (饥). Daily-ratesum means were derived by first averaging by seedlot across all years, and then across seedlots withing groups. Rate-sum means in this figure were calculated only for hours where the water potential was less negative than $-1.0 \mathrm{MPa}$. Vertical lines on $\mathrm{x}$-axis represent simulated planting dates. 
Figure 3. Annual-cumulative-rate sums for the 255-day test period as a function of seed subpopulation and seedlot-group for Bromus tectorum (^), Elymus multisetus $(\diamond)$, Pseudoroegneria spicata ( $\nabla)$, Elymus elymoides ssp. brevifolius Group C ( $)$, Elymus elymoides ssp. brevifolius Group B ( $\square$ ), Elymus elymoides ssp. elymoides ( $\Delta$ ), Elymus elymoides ssp. brevifolius Group A (०), Leymus cinereus wildland collections (closed octagon), Poa secunda ( $\bullet$ ), and Leymus cinereus released varieties (论). Vertical lines indicate the subpopulations used in the ANOVA and multiple comparison procedures. Figure 4. Mean-predicted cumulative germination response as a function of selected planting dates using all temperature data (4a) and temperature data only for hours where the water potential was estimated to be less negative than $-1.0 \mathrm{MPa}(4 \mathrm{~b})$ for Bromus tectorum (^), Elymus multisetus ( $\diamond)$, Pseudoroegneria spicata ( $\nabla)$, Elymus elymoides ssp. brevifolius Group C ( $)$, Elymus elymoides ssp. brevifolius Group B ( $\square$ ), Elymus elymoides ssp. elymoides ( $\triangle$ ), Elymus elymoides ssp. brevifolius Group A (०), Leymus cinereus wildland collections (closed octagon), Poa secunda ( $\downarrow$ ), and Leymus cinereus released varieties (饮). 
1

Table 1. Significance matrix for individual comparisons of mean-daily-germination-rate-sums for thermal accumulation across all water potentials as a function of seedlot-goup pair and selected planting dates for the $30 \%$ seed subpopulation. Each seedlot-goup is arranged in order of relative germination-

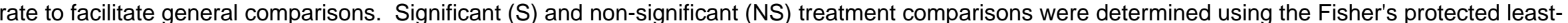
square-difference test for significant main-treatment effects. Brte (Bromus tectorum), Elmu (Elymus multisetus), Pssp (Pseudoroegneria spicata), ElelC (Elymus elymoides ssp. brevifolius Group C), ElelB (Elymus elymoides ssp. brevifolius Group B), Elel (Elymus elymoides ssp. elymoides), ElelA (Elymus elymoides ssp. brevifolius Group A), Pose (Poa secunda), LeciW (Leymus cinereus wildland collections varieties), LeciR (Leymus cinereus released varieties)

\begin{tabular}{|c|c|c|c|c|c|c|c|c|c|c|c|c|c|}
\hline \multirow[b]{2}{*}{ Species } & \multicolumn{6}{|c|}{ Planting Date } & \multicolumn{7}{|c|}{ Planting Date } \\
\hline & $30-\mathrm{Oc}$ & 1-De & $2-J a$ & $-M$ & $6-A p$ & 3-May & Species & $30-\mathrm{Oc}$ & 1-De & $2-J a$ & $5-M$ & $6-A p$ & 8-May \\
\hline Brte v. Elmu & $S$ & S & NS & $\mathrm{S}$ & $\mathrm{S}$ & $\mathrm{S}$ & Elel v. Brte & $\mathrm{S}$ & S & $\mathrm{S}$ & $\mathrm{S}$ & S & $\mathrm{S}$ \\
\hline Brte v. Pssp & S & $\mathrm{S}$ & $\mathrm{S}$ & $\mathrm{S}$ & $\mathrm{S}$ & $\mathrm{S}$ & Elel v. Elmu & $\mathrm{S}$ & S & $\mathrm{S}$ & S & $\mathrm{S}$ & $\mathrm{S}$ \\
\hline Brte v. ElelC & $S$ & S & $\mathrm{S}$ & $\mathrm{S}$ & S & $\mathrm{S}$ & Elel v. Pssp & $\mathrm{S}$ & NS & NS & $\mathrm{S}$ & $\mathrm{S}$ & NS \\
\hline Brte v. ElelB & $S$ & S & $\mathrm{S}$ & $\mathrm{S}$ & $\mathrm{S}$ & $\mathrm{S}$ & Elel v. ElelC & NS & NS & NS & NS & NS & NS \\
\hline Brte v. Elel & $S$ & $\mathrm{~S}$ & $\mathrm{~S}$ & $\mathrm{~S}$ & $\mathrm{~S}$ & $\mathrm{~S}$ & Elel v. ElelB & NS & NS & NS & NS & NS & NS \\
\hline Brte v. ElelA & $S$ & $\mathrm{~S}$ & $\mathrm{~S}$ & $\mathrm{~S}$ & S & $\mathrm{S}$ & Elel v. ElelA & NS & NS & NS & NS & NS & NS \\
\hline Brte v. Pose & $S$ & $\mathrm{~S}$ & $\mathrm{~S}$ & $\mathrm{~S}$ & S & $\mathrm{S}$ & Elel v. Pose & NS & NS & NS & NS & NS & NS \\
\hline Brte v. LeciW & $S$ & $\mathrm{~S}$ & $\mathrm{~S}$ & $\mathrm{~S}$ & S & $\mathrm{S}$ & Elel v. LeciW & NS & NS & NS & NS & NS & NS \\
\hline Brte v. LeciR & $S$ & $\mathrm{~S}$ & $\mathrm{~S}$ & $\mathrm{~S}$ & S & $\mathrm{S}$ & Elel v. LeciR & $\mathrm{S}$ & S & $\mathrm{S}$ & S & $\mathrm{S}$ & $\mathrm{S}$ \\
\hline Elmu v. Brte & $S$ & $\mathrm{~S}$ & NS & $\mathrm{S}$ & S & $\mathrm{S}$ & ElelA v. Brte & $\mathrm{S}$ & S & $\mathrm{S}$ & S & S & $\mathrm{S}$ \\
\hline Elmu v. Pssp & $S$ & S & $\mathrm{S}$ & $\mathrm{S}$ & NS & NS & ElelA v. Elmu & $\mathrm{S}$ & S & $\mathrm{S}$ & $\mathrm{S}$ & $\mathrm{S}$ & $\mathrm{S}$ \\
\hline Elmu v. ElelC & $S$ & $\mathrm{~S}$ & $\mathrm{~S}$ & $\mathrm{~S}$ & NS & NS & ElelA v. Pssp & $\mathrm{S}$ & S & $\mathrm{S}$ & S & $\mathrm{S}$ & $\mathrm{S}$ \\
\hline Elmu v. ElelB & $S$ & $\mathrm{~S}$ & $\mathrm{~S}$ & $\mathrm{~S}$ & S & NS & ElelA v. ElelC & NS & NS & NS & NS & $\mathrm{S}$ & $\mathrm{S}$ \\
\hline Elmu v. Elel & $S$ & $\mathrm{~S}$ & $\mathrm{~S}$ & $\mathrm{~S}$ & S & $\mathrm{S}$ & ElelA v. ElelB & NS & NS & NS & NS & NS & NS \\
\hline Elmu v. ElelA & $\mathrm{S}$ & $\mathrm{S}$ & $\mathrm{S}$ & $\mathrm{S}$ & $\mathrm{S}$ & $\mathrm{S}$ & ElelA v. Elel & NS & NS & NS & NS & NS & NS \\
\hline Elmu v. Pose & $S$ & $\mathrm{~S}$ & $\mathrm{~S}$ & $\mathrm{~S}$ & S & $\mathrm{S}$ & ElelA v. Pose & NS & NS & NS & NS & NS & NS \\
\hline Elmu v. LeciW & S & S & $\mathrm{S}$ & $\mathrm{S}$ & S & $\mathrm{S}$ & ElelA v. LeciW & NS & NS & NS & NS & NS & NS \\
\hline Elmu v. LeciR & S & $\mathrm{S}$ & $\mathrm{S}$ & $\mathrm{S}$ & S & $\mathrm{S}$ & ElelA v. LeciR & $\mathrm{S}$ & $\mathrm{S}$ & $\mathrm{S}$ & S & $\mathrm{S}$ & $\mathrm{S}$ \\
\hline
\end{tabular}




$\begin{array}{lcccccc}\text { Table 2. (continued) } & & & & & & \\ \text { Pssp v. Brte } & \text { S } & \text { S } & \text { S } & \text { S } & \text { S } & \text { S } \\ \text { Pssp v. Elmu } & \text { S } & \text { S } & \text { S } & \text { S } & \text { NS } & \text { NS } \\ \text { Pssp v. ElelC } & \text { NS } & \text { S } & \text { S } & \text { NS } & \text { NS } & \text { NS } \\ \text { Pssp v. ElelB } & \text { NS } & \text { NS } & \text { NS } & \text { NS } & \text { NS } & \text { NS } \\ \text { Pssp v. Elel } & \text { S } & \text { NS } & \text { NS } & \text { S } & \text { S } & \text { NS } \\ \text { Pssp v. ElelA } & \text { S } & \text { S } & \text { S } & \text { S } & \text { S } & \text { S } \\ \text { Pssp v. Pose } & \text { S } & \text { S } & \text { S } & \text { S } & \text { S } & \text { S } \\ \text { Pssp v. LeciW } & \text { S } & \text { S } & \text { S } & \text { S } & \text { S } & \text { S } \\ \text { Pssp v. LeciR } & \text { S } & \text { S } & \text { S } & \text { S } & \text { S } & \text { S } \\ & & & & & & \\ \text { ElelC v. Brte } & \text { S } & \text { S } & \text { S } & \text { S } & \text { S } & \text { S } \\ \text { ElelC v. Elmu } & \text { S } & \text { S } & \text { S } & \text { S } & \text { NS } & \text { NS } \\ \text { ElelC v. Pssp } & \text { NS } & \text { S } & \text { S } & \text { NS } & \text { NS } & \text { NS } \\ \text { ElelC v. ElelB } & \text { NS } & \text { NS } & \text { NS } & \text { NS } & \text { NS } & \text { NS } \\ \text { ElelC v. Elel } & \text { NS } & \text { NS } & \text { NS } & \text { NS } & \text { NS } & \text { NS } \\ \text { ElelC v. ElelA } & \text { NS } & \text { NS } & \text { NS } & \text { NS } & \text { S } & \text { S } \\ \text { ElelC v. Pose } & \text { NS } & \text { NS } & \text { NS } & \text { NS } & \text { S } & \text { NS } \\ \text { ElelC v. LeciW } & \text { S } & \text { NS } & \text { NS } & \text { S } & \text { S } & \text { NS } \\ \text { ElelC v. LeciR } & \text { S } & \text { S } & \text { S } & \text { S } & \text { S } & \text { S } \\ \text { ElelB v. Brte } & \text { S } & \text { S } & \text { S } & \text { S } & \text { S } & \text { S } \\ \text { ElelB v. Elmu } & \text { S } & \text { S } & \text { S } & \text { S } & \text { S } & \text { NS } \\ \text { ElelB v. Pssp } & \text { NS } & \text { NS } & \text { NS } & \text { NS } & \text { NS } & \text { NS } \\ \text { ElelB v. ElelC } & \text { NS } & \text { NS } & \text { NS } & \text { NS } & \text { NS } & \text { NS } \\ \text { ElelB v. Elel } & \text { NS } & \text { NS } & \text { NS } & \text { NS } & \text { NS } & \text { NS } \\ \text { ElelB v. ElelA } & \text { NS } & \text { NS } & \text { NS } & \text { NS } & \text { NS } & \text { NS } \\ \text { ElelB v. Pose } & \text { NS } & \text { NS } & \text { NS } & \text { NS } & \text { NS } & \text { NS } \\ \text { ElelB v. LeciW } & \text { NS } & \text { NS } & \text { NS } & \text { NS } & \text { NS } & \text { NS } \\ \text { ElelB v. LeciR } & \text { S } & \text { S } & \text { S } & \text { S } & \text { S } & \text { S }\end{array}$

$\begin{array}{lcccccc}\text { Pose v. Brte } & \text { S } & \text { S } & \text { S } & \text { S } & \text { S } & \text { S } \\ \text { Pose v. Elmu } & \text { S } & \text { S } & \text { S } & \text { S } & \text { S } & \text { S } \\ \text { Pose v. Pssp } & \text { S } & \text { S } & \text { S } & \text { S } & \text { S } & \text { S } \\ \text { Pose v. ElelC } & \text { NS } & \text { NS } & \text { NS } & \text { NS } & \text { S } & \text { NS } \\ \text { Pose v. ElelB } & \text { NS } & \text { NS } & \text { NS } & \text { NS } & \text { NS } & \text { NS } \\ \text { Pose v. Elel } & \text { NS } & \text { NS } & \text { NS } & \text { NS } & \text { NS } & \text { NS } \\ \text { Pose v. ElelA } & \text { NS } & \text { NS } & \text { NS } & \text { NS } & \text { NS } & \text { NS } \\ \text { Pose v. LeciW } & \text { NS } & \text { NS } & \text { NS } & \text { NS } & \text { NS } & \text { NS } \\ \text { Pose v. LeciR } & \text { S } & \text { S } & \text { NS } & \text { S } & \text { S } & \text { NS } \\ \text { LeciW v. Brte } & \text { S } & \text { S } & \text { S } & \text { S } & \text { S } & \text { S } \\ \text { LeciW v. Elmu } & \text { S } & \text { S } & \text { S } & \text { S } & \text { S } & \text { S } \\ \text { LeciW v. Pssp } & \text { S } & \text { S } & \text { S } & \text { S } & \text { S } & \text { S } \\ \text { LeciW v. ElelC } & \text { S } & \text { NS } & \text { NS } & \text { S } & \text { S } & \text { NS } \\ \text { LeciW v. ElelB } & \text { NS } & \text { NS } & \text { NS } & \text { NS } & \text { NS } & \text { NS } \\ \text { LeciW v. Elel } & \text { NS } & \text { NS } & \text { NS } & \text { NS } & \text { NS } & \text { NS } \\ \text { LeciW v. ElelA } & \text { NS } & \text { NS } & \text { NS } & \text { NS } & \text { NS } & \text { NS } \\ \text { LeciW v. Pose } & \text { NS } & \text { NS } & \text { NS } & \text { NS } & \text { NS } & \text { NS } \\ \text { LeciW v. LeciR } & \text { S } & \text { NS } & \text { NS } & \text { S } & \text { S } & \text { S } \\ & & & & & & \\ \text { LeciR v. Brte } & \text { S } & \text { S } & \text { S } & \text { S } & \text { S } & \text { S } \\ \text { LeciR v. Elmu } & \text { S } & \text { S } & \text { S } & \text { S } & \text { S } & \text { S } \\ \text { LeciR v. Pssp } & \text { S } & \text { S } & \text { S } & \text { S } & \text { S } & \text { S } \\ \text { LeciR v. ElelC } & \text { S } & \text { S } & \text { S } & \text { S } & \text { S } & \text { S } \\ \text { LeciR v. ElelB } & \text { S } & \text { S } & \text { S } & \text { S } & \text { S } & \text { S } \\ \text { LeciR v. Elel } & \text { S } & \text { S } & \text { S } & \text { S } & \text { S } & \text { S } \\ \text { LeciR v. ElelA } & \text { S } & \text { S } & \text { S } & \text { S } & \text { S } & \text { S } \\ \text { LeciR v. Pose } & \text { S } & \text { S } & \text { NS } & \text { S } & \text { S } & \text { NS } \\ \text { LeciR v. LeciW } & \text { S } & \text { NS } & \text { NS } & \text { S } & \text { S } & \text { S }\end{array}$


1

Table 2. Significance matrix for individual comparisons of mean-daily-germination-rate-sums for thermal accumulation for water potentials less negative than -1.0 MPa as a function of seedlot-goup pair and selected planting dates for the $30 \%$ seed subpopulation. Each seedlot-gourp is arranged in order of relative germination-rate to facilitate general comparisons. Significant (S) and non-significant (NS) treatment comparisons were determined using the Fisher's protected least-square-difference test for significant main-treatment effects. Brte (Bromus tectorum), Elmu (Elymus multisetus), Pssp

(Pseudoroegneria spicata), ElelC (Elymus elymoides ssp. brevifolius Group C), ElelB (Elymus elymoides ssp. brevifolius Group B), Elel (Elymus

elymoides ssp. elymoides), ElelA (Elymus elymoides ssp. brevifolius Group A), Pose (Poa secunda), LeciW (Leymus cinereus wildland collections), LeciR (Leymus cinereus released varieties).

\begin{tabular}{|c|c|c|c|c|c|c|c|c|c|c|c|c|c|}
\hline \multirow[b]{2}{*}{ Species } & \multicolumn{6}{|c|}{ Planting Date } & \multicolumn{7}{|c|}{ Planting Date } \\
\hline & $30-\mathrm{Oc}$ & 1-De & $2-J a$ & $-M$ & $6-A p$ & 3-May & Species & $30-\mathrm{Oc}$ & 1-De & $2-J a$ & $5-M$ & $6-A p$ & 8-May \\
\hline Brte v. Elmu & $S$ & S & NS & $\mathrm{S}$ & $\mathrm{S}$ & $\mathrm{S}$ & Elel v. Brte & $\mathrm{S}$ & S & $\mathrm{S}$ & $\mathrm{S}$ & S & $\mathrm{S}$ \\
\hline Brte v. Pssp & S & $\mathrm{S}$ & $\mathrm{S}$ & $\mathrm{S}$ & $\mathrm{S}$ & $\mathrm{S}$ & Elel v. Elmu & $\mathrm{S}$ & S & $\mathrm{S}$ & S & $\mathrm{S}$ & $\mathrm{S}$ \\
\hline Brte v. ElelC & $S$ & S & $\mathrm{S}$ & $\mathrm{S}$ & S & $\mathrm{S}$ & Elel v. Pssp & $\mathrm{S}$ & NS & NS & $\mathrm{S}$ & $\mathrm{S}$ & NS \\
\hline Brte v. ElelB & $S$ & S & $\mathrm{S}$ & $\mathrm{S}$ & $\mathrm{S}$ & $\mathrm{S}$ & Elel v. ElelC & NS & NS & NS & NS & NS & NS \\
\hline Brte v. Elel & $S$ & $\mathrm{~S}$ & $\mathrm{~S}$ & $\mathrm{~S}$ & $\mathrm{~S}$ & $\mathrm{~S}$ & Elel v. ElelB & NS & NS & NS & NS & NS & NS \\
\hline Brte v. ElelA & $S$ & $\mathrm{~S}$ & $\mathrm{~S}$ & $\mathrm{~S}$ & S & $\mathrm{S}$ & Elel v. ElelA & NS & NS & NS & NS & NS & NS \\
\hline Brte v. Pose & $S$ & $\mathrm{~S}$ & $\mathrm{~S}$ & $\mathrm{~S}$ & S & $\mathrm{S}$ & Elel v. Pose & NS & NS & NS & NS & NS & NS \\
\hline Brte v. LeciW & $S$ & $\mathrm{~S}$ & $\mathrm{~S}$ & $\mathrm{~S}$ & S & $\mathrm{S}$ & Elel v. LeciW & NS & NS & NS & NS & NS & NS \\
\hline Brte v. LeciR & $S$ & $\mathrm{~S}$ & $\mathrm{~S}$ & $\mathrm{~S}$ & S & $\mathrm{S}$ & Elel v. LeciR & $\mathrm{S}$ & S & $\mathrm{S}$ & S & $\mathrm{S}$ & $\mathrm{S}$ \\
\hline Elmu v. Brte & $S$ & $\mathrm{~S}$ & NS & $\mathrm{S}$ & S & $\mathrm{S}$ & ElelA v. Brte & $\mathrm{S}$ & S & $\mathrm{S}$ & S & S & $\mathrm{S}$ \\
\hline Elmu v. Pssp & $S$ & S & $\mathrm{S}$ & $\mathrm{S}$ & NS & NS & ElelA v. Elmu & $\mathrm{S}$ & S & $\mathrm{S}$ & $\mathrm{S}$ & $\mathrm{S}$ & $\mathrm{S}$ \\
\hline Elmu v. ElelC & $S$ & $\mathrm{~S}$ & $\mathrm{~S}$ & $\mathrm{~S}$ & NS & NS & ElelA v. Pssp & $\mathrm{S}$ & S & $\mathrm{S}$ & S & $\mathrm{S}$ & $\mathrm{S}$ \\
\hline Elmu v. ElelB & $S$ & $\mathrm{~S}$ & $\mathrm{~S}$ & $\mathrm{~S}$ & S & NS & ElelA v. ElelC & NS & NS & NS & NS & $\mathrm{S}$ & $\mathrm{S}$ \\
\hline Elmu v. Elel & $S$ & $\mathrm{~S}$ & $\mathrm{~S}$ & $\mathrm{~S}$ & S & $\mathrm{S}$ & ElelA v. ElelB & NS & NS & NS & NS & NS & NS \\
\hline Elmu v. ElelA & $\mathrm{S}$ & $\mathrm{S}$ & $\mathrm{S}$ & $\mathrm{S}$ & $\mathrm{S}$ & $\mathrm{S}$ & ElelA v. Elel & NS & NS & NS & NS & NS & NS \\
\hline Elmu v. Pose & $S$ & $\mathrm{~S}$ & $\mathrm{~S}$ & $\mathrm{~S}$ & S & $\mathrm{S}$ & ElelA v. Pose & NS & NS & NS & NS & NS & NS \\
\hline Elmu v. LeciW & S & S & $\mathrm{S}$ & $\mathrm{S}$ & S & $\mathrm{S}$ & ElelA v. LeciW & NS & NS & NS & NS & NS & NS \\
\hline Elmu v. LeciR & S & $\mathrm{S}$ & $\mathrm{S}$ & $\mathrm{S}$ & S & $\mathrm{S}$ & ElelA v. LeciR & $\mathrm{S}$ & $\mathrm{S}$ & $\mathrm{S}$ & S & $\mathrm{S}$ & $\mathrm{S}$ \\
\hline
\end{tabular}




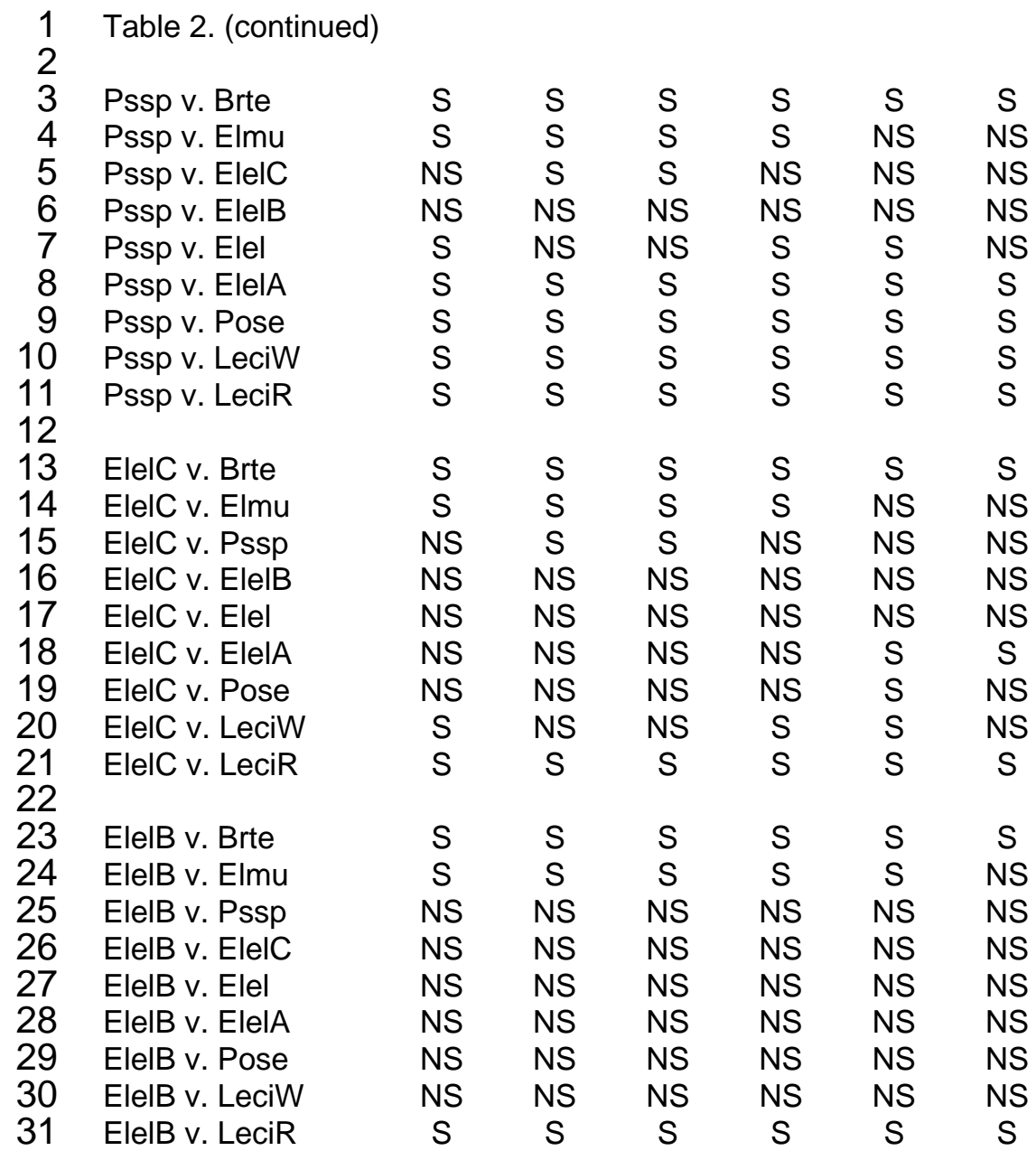

$\begin{array}{lcccccc}\text { Pose v. Brte } & \text { S } & \text { S } & \text { S } & \text { S } & \text { S } & \text { S } \\ \text { Pose v. Elmu } & \text { S } & \text { S } & \text { S } & \text { S } & \text { S } & \text { S } \\ \text { Pose v. Pssp } & \text { S } & \text { S } & \text { S } & \text { S } & \text { S } & \text { S } \\ \text { Pose v. ElelC } & \text { NS } & \text { NS } & \text { NS } & \text { NS } & \text { S } & \text { NS } \\ \text { Pose v. ElelB } & \text { NS } & \text { NS } & \text { NS } & \text { NS } & \text { NS } & \text { NS } \\ \text { Pose v. Elel } & \text { NS } & \text { NS } & \text { NS } & \text { NS } & \text { NS } & \text { NS } \\ \text { Pose v. ElelA } & \text { NS } & \text { NS } & \text { NS } & \text { NS } & \text { NS } & \text { NS } \\ \text { Pose v. LeciW } & \text { NS } & \text { NS } & \text { NS } & \text { NS } & \text { NS } & \text { NS } \\ \text { Pose v. LeciR } & \text { S } & \text { S } & \text { NS } & \text { S } & \text { S } & \text { NS } \\ \text { LeciW v. Brte } & \text { S } & \text { S } & \text { S } & \text { S } & \text { S } & \text { S } \\ \text { LeciW v. Elmu } & \text { S } & \text { S } & \text { S } & \text { S } & \text { S } & \text { S } \\ \text { LeciW v. Pssp } & \text { S } & \text { S } & \text { S } & \text { S } & \text { S } & \text { S } \\ \text { LeciW v. ElelC } & \text { S } & \text { NS } & \text { NS } & \text { S } & \text { S } & \text { NS } \\ \text { LeciW v. ElelB } & \text { NS } & \text { NS } & \text { NS } & \text { NS } & \text { NS } & \text { NS } \\ \text { LeciW v. Elel } & \text { NS } & \text { NS } & \text { NS } & \text { NS } & \text { NS } & \text { NS } \\ \text { LeciW v. ElelA } & \text { NS } & \text { NS } & \text { NS } & \text { NS } & \text { NS } & \text { NS } \\ \text { LeciW v. Pose } & \text { NS } & \text { NS } & \text { NS } & \text { NS } & \text { NS } & \text { NS } \\ \text { LeciW v. LeciR } & \text { S } & \text { NS } & \text { NS } & \text { S } & \text { S } & \text { S } \\ & & & & & & \\ \text { LeciR v. Brte } & \text { S } & \text { S } & \text { S } & \text { S } & \text { S } & \text { S } \\ \text { LeciR v. Elmu } & \text { S } & \text { S } & \text { S } & \text { S } & \text { S } & \text { S } \\ \text { LeciR v. PsSp } & \text { S } & \text { S } & \text { S } & \text { S } & \text { S } & \text { S } \\ \text { LeciR v. ElelC } & \text { S } & \text { S } & \text { S } & \text { S } & \text { S } & \text { S } \\ \text { LeciR v. ElelB } & \text { S } & \text { S } & \text { S } & \text { S } & \text { S } & \text { S } \\ \text { LeciR v. Elel } & \text { S } & \text { S } & \text { S } & \text { S } & \text { S } & \text { S } \\ \text { LeciR v. ElelA } & \text { S } & \text { S } & \text { S } & \text { S } & \text { S } & \text { S } \\ \text { LeciR v. Pose } & \text { S } & \text { S } & \text { NS } & \text { S } & \text { S } & \text { NS } \\ \text { LeciR v. LeciW } & \text { S } & \text { NS } & \text { NS } & \text { S } & \text { S } & \text { S }\end{array}$


1 Table 3. Significance matrix for individual comparisons of annual-cumulative-rate-sums as a function seedlot-gourp pair and selected subpopulations. Each seedlot-group is arranged in order of relative germination-rate to facilitate general comparisons. Significant (S) and non-significant (NS) treatment comparisons were determined using the Fisher's protected least-square-difference test for significant main-treatment effects. Brte (Bromus tectorum),

Elmu (Elymus multisetus), Pssp (Pseudoroegneria spicata), ElelC (Elymus elymoides ssp. brevifolius Group C), ElelB (Elymus elymoides ssp. brevifolius Group B), Elel (Elymus elymoides ssp. elymoides), ElelA (Elymus elymoides ssp. brevifolius Group A), Pose (Poa secunda), LeciW (Leymus cinereus wildland collections), LeciR (Leymus cinereus released varieties).

\begin{tabular}{|c|c|c|c|c|c|c|c|c|c|}
\hline Species & $10 \%$ & $30 \%$ & $50 \%$ & $70 \%$ & Species & $10 \%$ & $30 \%$ & $50 \%$ & $70 \%$ \\
\hline Brte v. Elmu & S & S & S & S & Elel v. Brte & S & S & $\mathrm{S}$ & $\mathrm{S}$ \\
\hline Brte v. Pssp & $\mathrm{S}$ & $\mathrm{S}$ & $\mathrm{S}$ & NS & Elel v. Elmu & $\mathrm{S}$ & $\mathrm{S}$ & $\mathrm{S}$ & NS \\
\hline Brte v. ElelC & $\mathrm{S}$ & $\mathrm{S}$ & $\mathrm{S}$ & NS & Elel v. Pssp & NS & $\mathrm{S}$ & $\mathrm{S}$ & $\mathrm{S}$ \\
\hline Brte v. ElelB & $\mathrm{S}$ & $\mathrm{S}$ & $\mathrm{S}$ & $\mathrm{S}$ & Elel v. ElelC & NS & NS & NS & NS \\
\hline Brte v. Pose & $\mathrm{S}$ & $\mathrm{S}$ & $\mathrm{S}$ & $\mathrm{S}$ & Elel v. Pose & NS & NS & NS & NS \\
\hline Brte v. LeciW & $\mathrm{S}$ & $\mathrm{S}$ & $\mathrm{S}$ & $\mathrm{S}$ & Elel v. LeciW & NS & NS & NS & NS \\
\hline Brte v. LeciR & S & $\mathrm{S}$ & $\mathrm{S}$ & $\mathrm{S}$ & Elel v. LeciR & $\mathrm{S}$ & $\mathrm{S}$ & $S$ & $\mathrm{~S}$ \\
\hline Elmu v. Brte & $\mathrm{s}$ & $\mathrm{s}$ & $\mathrm{S}$ & $\mathrm{S}$ & ElelA v. Brte & $\mathrm{S}$ & $\mathrm{S}$ & $\mathrm{S}$ & $\mathrm{S}$ \\
\hline Elmu v. Pssp & NS & NS & NS & NS & ElelA v. Elmu & $\mathrm{S}$ & $\mathrm{S}$ & $\mathrm{S}$ & NS \\
\hline Elmu v. LeciW & $\mathrm{S}$ & $\mathrm{S}$ & $\mathrm{s}$ & $\mathrm{S}$ & ElelA v. LeciW & NS & NS & NS & $\mathrm{s}$ \\
\hline Elmu v. LeciR & $\mathrm{S}$ & $\mathrm{S}$ & $\mathrm{S}$ & $\mathrm{S}$ & ElelA v. LeciR & $\mathrm{S}$ & $\mathrm{S}$ & $\mathrm{S}$ & S \\
\hline
\end{tabular}




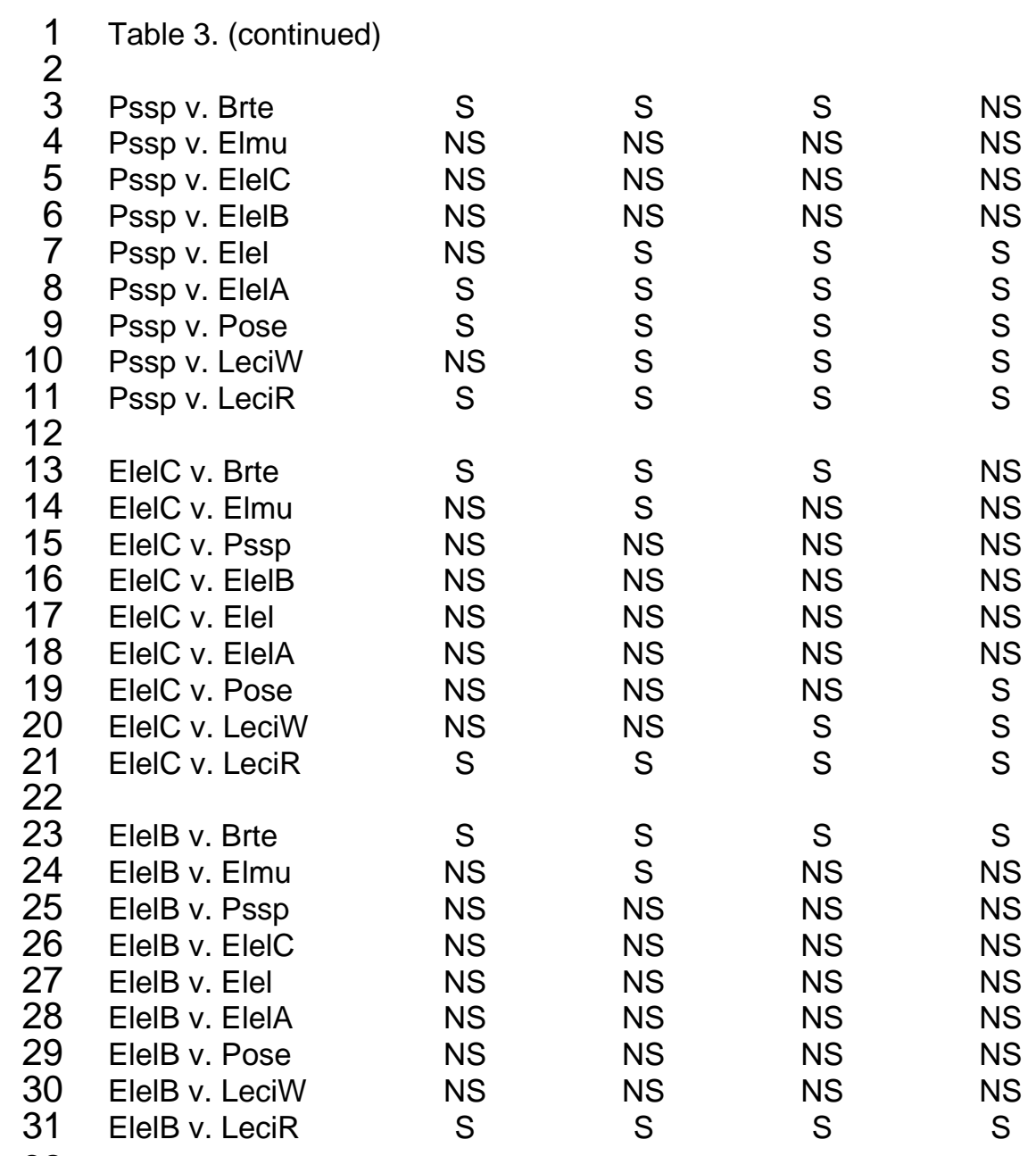

$\begin{array}{lcccc}\text { Pose v. Brte } & \text { S } & \text { S } & \text { S } & \text { S } \\ \text { Pose v. Elmu } & \text { S } & \text { S } & \text { S } & \text { S } \\ \text { Pose v. Pssp } & \text { S } & \text { S } & \text { S } & \text { S } \\ \text { Pose v. ElelC } & \text { NS } & \text { NS } & \text { NS } & \text { S } \\ \text { Pose v. ElelB } & \text { NS } & \text { NS } & \text { NS } & \text { NS } \\ \text { Pose v. Elel } & \text { NS } & \text { NS } & \text { NS } & \text { NS } \\ \text { Pose v. ElelA } & \text { NS } & \text { NS } & \text { NS } & \text { NS } \\ \text { Pose v. LeciW } & \text { NS } & \text { NS } & \text { NS } & \text { NS } \\ \text { Pose v. LeciR } & \text { NS } & \text { S } & \text { S } & \text { S }\end{array}$

LeciW v. Brte $\quad S \quad S \quad S \quad S \quad S$


Table 4. Significance matrix for individual comparisons of mean-germination-times for thermal accumulation as a function of planting date, water-potential range, seedlot-group pair, and selected subpopulations. Each seedlot-goup is arranged in order of relative germination-rate to facilitate general comparisons. Significant (S) and non-significant (NS) treatment comparisons were determined using the Fisher's protected least-square-difference test for significant main-treatment effects. Brte (Bromus tectorum), Elmu (Elymus multisetus), Pssp (Pseudoroegneria spicata), ElelC (Elymus elymoides ssp. brevifolius Group C), ElelB (Elymus elymoides ssp. brevifolius Group B), Elel (Elymus elymoides ssp. elymoides), ElelA (Elymus elymoides ssp. brevifolius Group A), Pose (Poa secunda), LeciW (Leymus cinereus wildland collections varieties), LeciR (Leymus cinereus released varieties).

\begin{tabular}{|c|c|c|c|c|c|c|c|c|c|c|c|c|}
\hline \multirow[b]{3}{*}{ Species } & \multicolumn{4}{|c|}{ 11-Dec } & \multicolumn{4}{|c|}{ 05-Mar } & \multicolumn{4}{|c|}{ 28-May } \\
\hline & \multicolumn{2}{|c|}{ all } & \multicolumn{2}{|c|}{ >-1.0MPa } & \multicolumn{2}{|c|}{ all } & \multicolumn{2}{|c|}{$>-1.0 \mathrm{MPa}$} & \multicolumn{2}{|c|}{ all } & \multicolumn{2}{|c|}{ >-1.0MPa } \\
\hline & $10 \%$ & $50 \%$ & $10 \%$ & $50 \%$ & $10 \%$ & $50 \%$ & $10 \%$ & $50 \%$ & $10 \%$ & $50 \%$ & $10 \%$ & $50 \%$ \\
\hline Brte v. Elmu & $\mathrm{S}$ & NS & $\mathrm{S}$ & NS & $\mathrm{S}$ & NS & $\mathrm{S}$ & NS & $\mathrm{S}$ & NS & $\mathrm{S}$ & $\mathrm{S}$ \\
\hline Brte v. Pssp & $\mathrm{S}$ & NS & $\mathrm{S}$ & NS & $\mathrm{S}$ & NS & $\mathrm{S}$ & $\mathrm{S}$ & $\mathrm{S}$ & $\mathrm{S}$ & $\mathrm{S}$ & $\mathrm{S}$ \\
\hline Brte v. ElelC & $\mathrm{S}$ & $\mathrm{S}$ & $\mathrm{S}$ & $\mathrm{S}$ & $\mathrm{S}$ & $\mathrm{S}$ & $\mathrm{S}$ & $\mathrm{S}$ & $\mathrm{S}$ & $\mathrm{S}$ & $\mathrm{S}$ & $\mathrm{S}$ \\
\hline Brte v. ElelB & $\mathrm{S}$ & NS & $\mathrm{S}$ & NS & $\mathrm{S}$ & $\mathrm{S}$ & $\mathrm{S}$ & $\mathrm{S}$ & $\mathrm{S}$ & $\mathrm{S}$ & $\mathrm{S}$ & $\mathrm{S}$ \\
\hline Brte v. Elel & $\mathrm{S}$ & NS & $\mathrm{S}$ & NS & $\mathrm{S}$ & $\mathrm{S}$ & $\mathrm{S}$ & $\mathrm{S}$ & $\mathrm{S}$ & $\mathrm{S}$ & $\mathrm{S}$ & $\mathrm{S}$ \\
\hline Brte v. ElelA & $\mathrm{S}$ & $\mathrm{S}$ & $\mathrm{S}$ & $\mathrm{S}$ & $\mathrm{S}$ & $\mathrm{S}$ & $\mathrm{S}$ & $\mathrm{S}$ & $\mathrm{S}$ & $\mathrm{S}$ & $\mathrm{S}$ & $\mathrm{S}$ \\
\hline Brte v. Pose & $\mathrm{S}$ & $\mathrm{S}$ & $\mathrm{S}$ & $\mathrm{S}$ & $\mathrm{S}$ & $\mathrm{S}$ & $\mathrm{S}$ & $\mathrm{S}$ & $\mathrm{S}$ & $\mathrm{S}$ & $\mathrm{S}$ & $\mathrm{S}$ \\
\hline Brte v. LeciW & $\mathrm{S}$ & $\mathrm{S}$ & $\mathrm{S}$ & $\mathrm{S}$ & $\mathrm{S}$ & $\mathrm{S}$ & $\mathrm{S}$ & $\mathrm{S}$ & $\mathrm{S}$ & $\mathrm{S}$ & $\mathrm{S}$ & $\mathrm{S}$ \\
\hline Brte v. LeciR & $S$ & $\mathrm{~S}$ & $\mathrm{~S}$ & $\mathrm{~S}$ & $\mathrm{~S}$ & $\mathrm{~S}$ & $\mathrm{~S}$ & $\mathrm{~S}$ & $\mathrm{~S}$ & - & $\mathrm{S}$ & - \\
\hline Elmu v. Brte & $\mathrm{S}$ & NS & $\mathrm{S}$ & NS & $\mathrm{S}$ & NS & $\mathrm{S}$ & NS & $\mathrm{S}$ & NS & $\mathrm{S}$ & $\mathrm{S}$ \\
\hline Elmu v. Pssp & NS & NS & NS & NS & NS & NS & NS & NS & NS & NS & $\mathrm{S}$ & NS \\
\hline Elmu v. ElelC & $\mathrm{S}$ & $\mathrm{S}$ & $\mathrm{S}$ & $\mathrm{S}$ & $\mathrm{S}$ & $\mathrm{S}$ & NS & $\mathrm{S}$ & NS & NS & NS & NS \\
\hline Elmu v. ElelB & $\mathrm{S}$ & $\mathrm{S}$ & NS & NS & $\mathrm{S}$ & NS & $\mathrm{S}$ & $\mathrm{S}$ & $\mathrm{S}$ & NS & $\mathrm{S}$ & $S$ \\
\hline Elmu v. Elel & $\mathrm{S}$ & $\mathrm{S}$ & $\mathrm{S}$ & NS & $\mathrm{S}$ & $\mathrm{S}$ & $\mathrm{S}$ & $\mathrm{S}$ & $\mathrm{S}$ & NS & $\mathrm{S}$ & $\mathrm{S}$ \\
\hline Elmu v. ElelA & $\mathrm{S}$ & $\mathrm{S}$ & $\mathrm{S}$ & $\mathrm{S}$ & $\mathrm{S}$ & $\mathrm{S}$ & $\mathrm{S}$ & $\mathrm{S}$ & $\mathrm{S}$ & $\mathrm{S}$ & $\mathrm{S}$ & $S$ \\
\hline Elmu v. Pose & $\mathrm{S}$ & $\mathrm{S}$ & $\mathrm{S}$ & $\mathrm{S}$ & $\mathrm{S}$ & $\mathrm{S}$ & $\mathrm{S}$ & $\mathrm{S}$ & $\mathrm{S}$ & $\mathrm{S}$ & $\mathrm{S}$ & $\mathrm{S}$ \\
\hline Elmu v. LeciW & $\mathrm{S}$ & $\mathrm{S}$ & $\mathrm{S}$ & $\mathrm{S}$ & $\mathrm{S}$ & $\mathrm{S}$ & $\mathrm{S}$ & $\mathrm{S}$ & $\mathrm{S}$ & $\mathrm{S}$ & $\mathrm{S}$ & $S$ \\
\hline Elmu v. LeciR & $\mathrm{S}$ & $\mathrm{S}$ & $\mathrm{S}$ & $\mathrm{S}$ & $\mathrm{S}$ & $\mathrm{S}$ & $\mathrm{S}$ & $\mathrm{S}$ & $\mathrm{S}$ & - & $\mathrm{S}$ & - \\
\hline
\end{tabular}




\begin{tabular}{|c|c|c|c|c|c|c|c|c|c|c|c|c|}
\hline Pssp v. Brte & $S$ & NS & $S$ & NS & $\mathrm{S}$ & NS & $S$ & $\mathrm{~S}$ & $S$ & $S$ & S & $S$ \\
\hline Pssp v. Elmu & NS & NS & NS & NS & NS & NS & NS & NS & NS & NS & $\mathrm{S}$ & NS \\
\hline Pssp v. ElelC & NS & NS & NS & NS & NS & NS & NS & NS & NS & NS & NS & NS \\
\hline Pssp v. ElelB & NS & NS & NS & NS & NS & NS & NS & NS & NS & NS & NS & NS \\
\hline Pssp v. Elel & NS & NS & NS & NS & NS & NS & NS & NS & NS & NS & NS & NS \\
\hline Pssp v. ElelA & $S$ & $\mathrm{~S}$ & $\mathrm{~S}$ & $\mathrm{~S}$ & $\mathrm{~S}$ & $S$ & $S$ & $\mathrm{~S}$ & $\mathrm{~S}$ & $S$ & $S$ & $S$ \\
\hline Pssp v. Pose & NS & $\mathrm{S}$ & NS & $\mathrm{S}$ & $\mathrm{S}$ & $\mathrm{S}$ & $\mathrm{S}$ & $\mathrm{S}$ & $\mathrm{S}$ & $\mathrm{S}$ & $\mathrm{S}$ & $\mathrm{S}$ \\
\hline Pssp v. LeciW & $\mathrm{S}$ & $\mathrm{S}$ & $\mathrm{S}$ & $\mathrm{S}$ & $\mathrm{S}$ & $\mathrm{S}$ & $\mathrm{S}$ & $\mathrm{s}$ & NS & $\mathrm{S}$ & $\mathrm{S}$ & $\mathrm{S}$ \\
\hline Pssp v. LeciR & $S$ & S & $S$ & $S$ & $S$ & $\mathrm{~S}$ & S & S & $\mathrm{S}$ & - & $\mathrm{S}$ & - \\
\hline ElelC v. Brte & $S$ & S & S & $S$ & $S$ & $S$ & S & S & $\mathrm{S}$ & $\mathrm{S}$ & $\mathrm{S}$ & S \\
\hline ElelC v. Elmu & $\mathrm{S}$ & $\mathrm{S}$ & $\mathrm{S}$ & $\mathrm{S}$ & $\mathrm{S}$ & $\mathrm{S}$ & NS & $\mathrm{S}$ & NS & NS & NS & NS \\
\hline ElelC v. Pssp & NS & NS & NS & NS & NS & NS & NS & NS & NS & NS & NS & NS \\
\hline ElelC v. ElelB & NS & NS & NS & NS & NS & NS & NS & NS & NS & NS & NS & NS \\
\hline ElelC v. Elel & NS & NS & NS & NS & NS & NS & NS & NS & NS & NS & NS & NS \\
\hline ElelC v. ElelA & $\mathrm{s}$ & NS & $\mathrm{S}$ & NS & S & NS & $\mathrm{S}$ & NS & $\mathrm{S}$ & $\mathrm{S}$ & $\mathrm{S}$ & 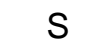 \\
\hline ElelC v. Pose & NS & NS & NS & NS & $\mathrm{S}$ & NS & $\mathrm{S}$ & NS & $\mathrm{S}$ & $\mathrm{S}$ & $\mathrm{S}$ & $\mathrm{S}$ \\
\hline ElelC v. LeciW & NS & $\mathrm{S}$ & NS & $S$ & $S$ & $S$ & S & $\mathrm{S}$ & NS & $S$ & $\mathrm{~S}$ & $S$ \\
\hline ElelC v. LeciR & $S$ & S & $\mathrm{S}$ & $\mathrm{S}$ & S & $\mathrm{S}$ & $\mathrm{S}$ & $\mathrm{S}$ & $\mathrm{S}$ & - & $\mathrm{S}$ & \\
\hline ElelB v. Brte & S & NS & S & NS & $S$ & $\mathrm{~S}$ & $\mathrm{~S}$ & $\mathrm{~s}$ & $\mathrm{~S}$ & $\mathrm{~S}$ & $\mathrm{~S}$ & S \\
\hline ElelB v. Elmu & $\mathrm{S}$ & $\mathrm{S}$ & NS & NS & $\mathrm{S}$ & NS & S & $\mathrm{S}$ & $\mathrm{S}$ & NS & $\mathrm{S}$ & \\
\hline ElelB v. Pssp & NS & NS & NS & NS & NS & NS & NS & NS & NS & NS & NS & $\mathrm{N}$ \\
\hline ElelB v. ElelC & NS & NS & NS & NS & NS & NS & NS & NS & NS & NS & NS & $\mathrm{N}$ \\
\hline ElelB v. Elel & NS & NS & NS & NS & NS & NS & NS & NS & NS & NS & NS & $\mathrm{N}$ \\
\hline ElelB v. ElelA & NS & NS & NS & NS & NS & NS & NS & NS & NS & NS & NS & \\
\hline ElelB v. Pose & NS & NS & NS & NS & NS & NS & NS & NS & NS & $\mathrm{S}$ & NS & 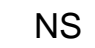 \\
\hline ElelB v. LeciW & NS & $\mathrm{S}$ & NS & $\mathrm{S}$ & NS & $\mathrm{S}$ & NS & $S$ & NS & NS & NS & $\mathrm{N}$ \\
\hline ElelB v. LeciR & $S$ & $\mathrm{~S}$ & $S$ & $\mathrm{~S}$ & $\mathrm{~S}$ & $\mathrm{~S}$ & $\mathrm{~s}$ & $\mathrm{~S}$ & $S$ & - & $S$ & \\
\hline
\end{tabular}




\section{Table 4. (continued)}

Elel v. Brte

Elel v. Elmu

Elel v. Pssp

Elel v. ElelC

Elel v. ElelB

Elel v. ElelA

Elel v. Pose

Elel v. LeciW

Elel v. LeciR

ElelA v. Brte

ElelA v. EImu

ElelA v. Pssp

ElelA v. ElelC

ElelA v. ElelB

ElelA v. Elel

ElelA v. Pose

ElelA v. LeciW

ElelA v. LeciR

Pose v. Brte

Pose v. Elmu

Pose v. Pssp

Pose v. ElelC

Pose v. ElelB

Pose v. Elel

Pose v. ElelA

Pose v. LeciW

Pose v. LeciR

$\begin{array}{cccc}\text { S } & \text { NS } & \text { S } & \text { NS } \\ \text { S } & \text { S } & \text { S } & \text { NS } \\ \text { NS } & \text { NS } & \text { NS } & \text { NS } \\ \text { NS } & \text { NS } & \text { NS } & \text { NS } \\ \text { NS } & \text { NS } & \text { NS } & \text { NS } \\ \text { NS } & \text { NS } & \text { NS } & \text { NS } \\ \text { NS } & \text { NS } & \text { NS } & \text { NS } \\ \text { NS } & \text { S } & \text { NS } & \text { S } \\ \text { S } & \text { S } & \text { S } & \text { S }\end{array}$

$\begin{array}{cccc}S & S & S & S \\ S & S & S & S \\ N S & N S & N S & N S \\ N S & N S & N S & N S \\ N S & N S & N S & N S \\ N S & N S & N S & N S \\ N S & N S & N S & N S \\ N S & S & N S & S \\ S & S & S & S\end{array}$

$\begin{array}{cccc}\text { S } & \text { S } & \text { S } & \text { S } \\ \text { S } & \text { NS } & \text { S } & \text { S } \\ \text { NS } & \text { NS } & \text { NS } & \text { NS } \\ \text { NS } & \text { NS } & \text { NS } & \text { NS } \\ \text { NS } & \text { NS } & \text { NS } & \text { NS } \\ \text { NS } & \text { NS } & \text { NS } & \text { NS } \\ \text { S } & \text { S } & \text { NS } & \text { S } \\ \text { NS } & \text { S } & \text { NS } & \text { S } \\ \text { S } & - & \text { S } & -\end{array}$

\begin{tabular}{|c|c|c|}
\hline S & $S$ & $S$ \\
\hline S & $S$ & $S$ \\
\hline S & $S$ & $S$ \\
\hline$S$ & NS & $S$ \\
\hline NS & NS & NS \\
\hline NS & NS & NS \\
\hline NS & NS & NS \\
\hline NS & $S$ & NS \\
\hline$S$ & $S$ & $S$ \\
\hline$S$ & $S$ & $S$ \\
\hline S & $S$ & S \\
\hline$S$ & $S$ & $S$ \\
\hline$S$ & NS & $S$ \\
\hline NS & NS & NS \\
\hline NS & NS & NS \\
\hline NS & NS & NS \\
\hline NS & NS & NS \\
\hline S & $S$ & $S$ \\
\hline
\end{tabular}

$\begin{array}{cccc}\text { S } & \text { S } & \text { S } & \text { S } \\ \text { S } & \text { S } & \text { S } & \text { S } \\ \text { S } & \text { S } & \text { S } & \text { S } \\ \text { S } & \text { S } & \text { S } & \text { S } \\ \text { NS } & \text { NS } & \text { NS } & \text { NS } \\ \text { NS } & \text { NS } & \text { NS } & \text { NS } \\ \text { NS } & \text { S } & \text { NS } & \text { NS } \\ \text { NS } & \text { NS } & \text { NS } & \text { S } \\ \text { S } & - & \text { S } & - \\ & & & \\ \text { S } & \text { S } & \text { S } & \text { S } \\ \text { S } & \text { S } & \text { S } & \text { S } \\ \text { S } & \text { S } & \text { S } & \text { S } \\ \text { S } & \text { S } & \text { S } & \text { S } \\ \text { NS } & \text { S } & \text { NS } & \text { NS } \\ \text { S } & \text { S } & \text { NS } & \text { S } \\ \text { NS } & \text { S } & \text { NS } & \text { NS } \\ \text { NS } & \text { NS } & \text { NS } & \text { NS } \\ \text { S } & - & \text { S } & -\end{array}$




$\begin{aligned} 1 & \text { Table 4. (continued) } \\ 2 & \\ 3 & \text { LeciW v. Brte } \\ 4 & \text { LeciW v. Elmu } \\ 5 & \text { LeciW v. Pssp } \\ 6 & \text { LeciW v. ElelC } \\ 7 & \text { LeciW v. ElelB } \\ 8 & \text { LeciW v. Elel } \\ 9 & \text { LeciW v. ElelA } \\ 10 & \text { LeciW v. Pose } \\ 11 & \text { LeciW v. LeciR } \\ 12 & \\ 13 & \text { LeciR v. Brte } \\ 14 & \text { LeciR v. Elmu } \\ 15 & \text { LeciR v. Pssp } \\ 16 & \text { LeciR v. ElelC } \\ 17 & \text { LeciR v. ElelB } \\ 18 & \text { LeciR v. Elel } \\ 19 & \text { LeciR v. ElelA } \\ 20 & \text { LeciR v. Pose } \\ 21 & \text { LeciR v. LeciW } \\ 22 & \end{aligned}$

$\begin{array}{cccc}\text { S } & \text { S } & \text { S } & \text { S } \\ S & S & S & S \\ S & S & S & S \\ N S & S & N S & S \\ N S & S & N S & S \\ N S & S & N S & S \\ N S & S & N S & S \\ N S & N S & N S & S \\ S & S & S & S \\ & & & \\ S & S & S & S \\ S & S & S & S \\ S & S & S & S \\ S & S & S & S \\ S & S & S & S \\ S & S & S & S \\ S & S & S & S \\ S & S & S & S \\ S & S & S & S\end{array}$

\begin{tabular}{|c|c|c|c|}
\hline $\mathrm{S}$ & $S$ & $S$ & $\mathrm{~S}$ \\
\hline$S$ & $S$ & $S$ & $S$ \\
\hline NS & $\mathrm{S}$ & S & $\mathrm{S}$ \\
\hline NS & $S$ & $S$ & $S$ \\
\hline NS & NS & NS & NS \\
\hline NS & $S$ & NS & $S$ \\
\hline NS & NS & NS & $S$ \\
\hline NS & NS & NS & NS \\
\hline$S$ & - & S & - \\
\hline $\mathrm{S}$ & - & S & - \\
\hline$S$ & - & S & - \\
\hline$S$ & - & $S$ & - \\
\hline$S$ & - & $S$ & - \\
\hline$S$ & - & S & - \\
\hline$S$ & - & $S$ & - \\
\hline$S$ & - & $S$ & - \\
\hline$S$ & - & S & - \\
\hline$S$ & - & S & \\
\hline
\end{tabular}



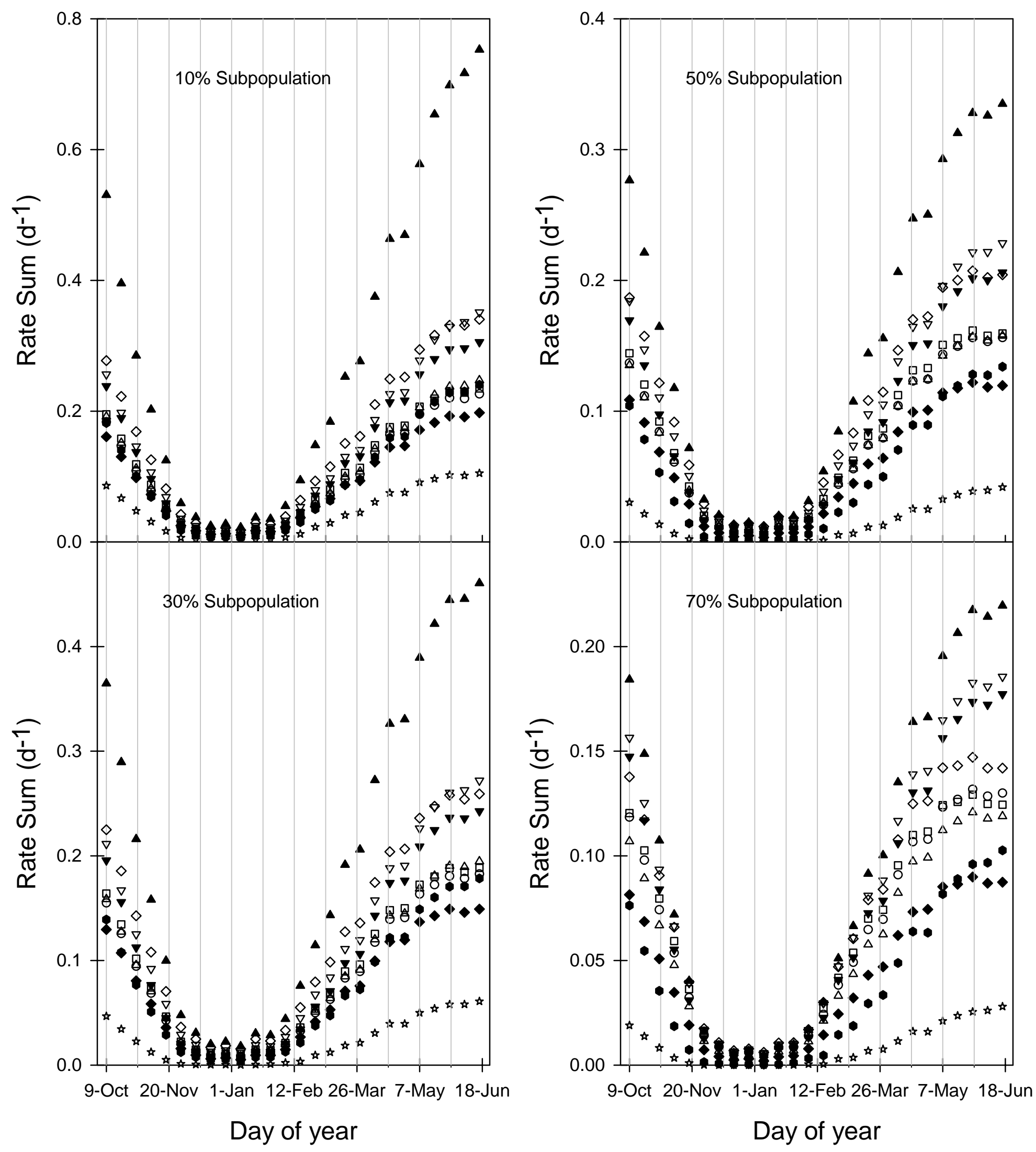

Fig. 1 


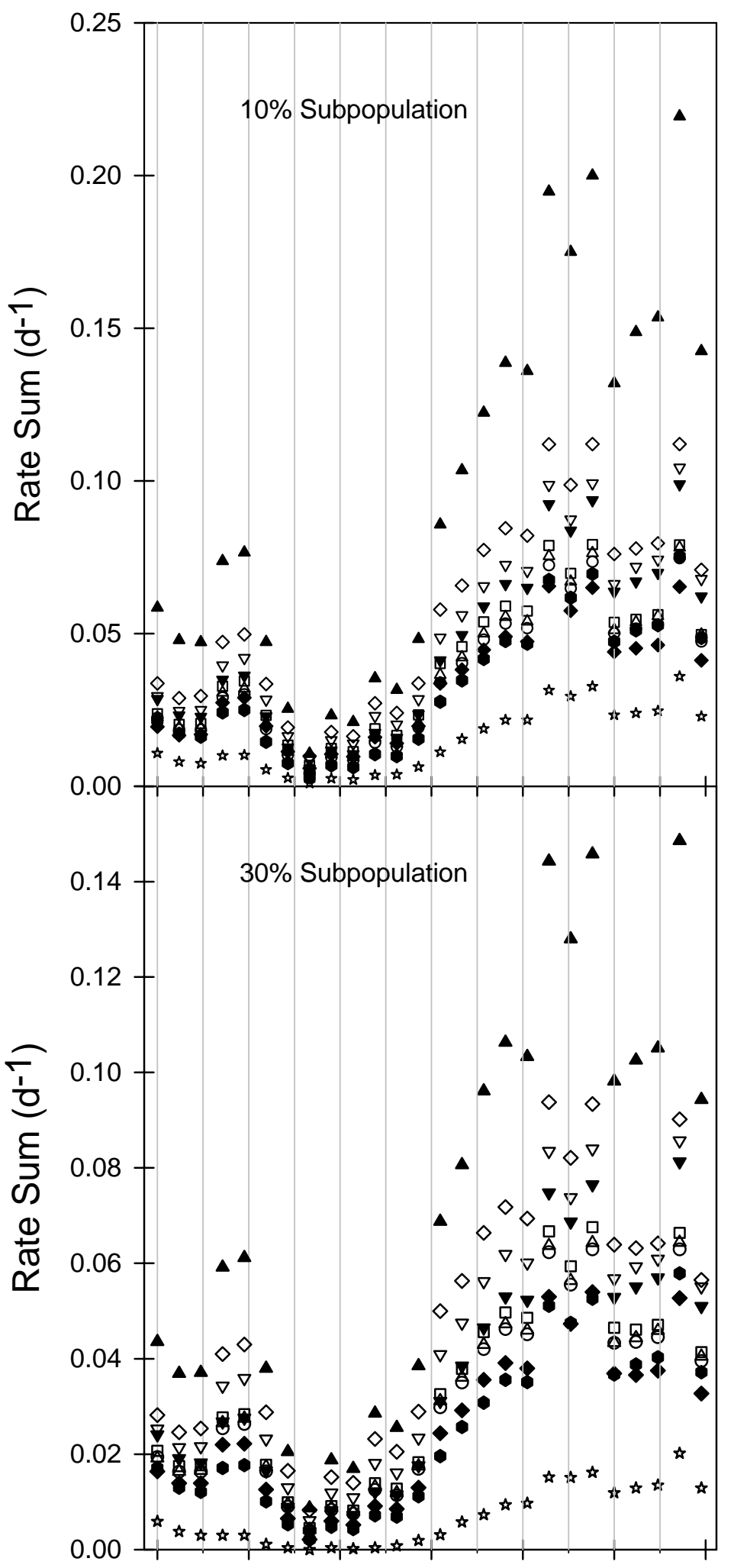

9-Oct 20-Nov 1-Jan 12-Feb 26-Mar 7-May 18-Jun

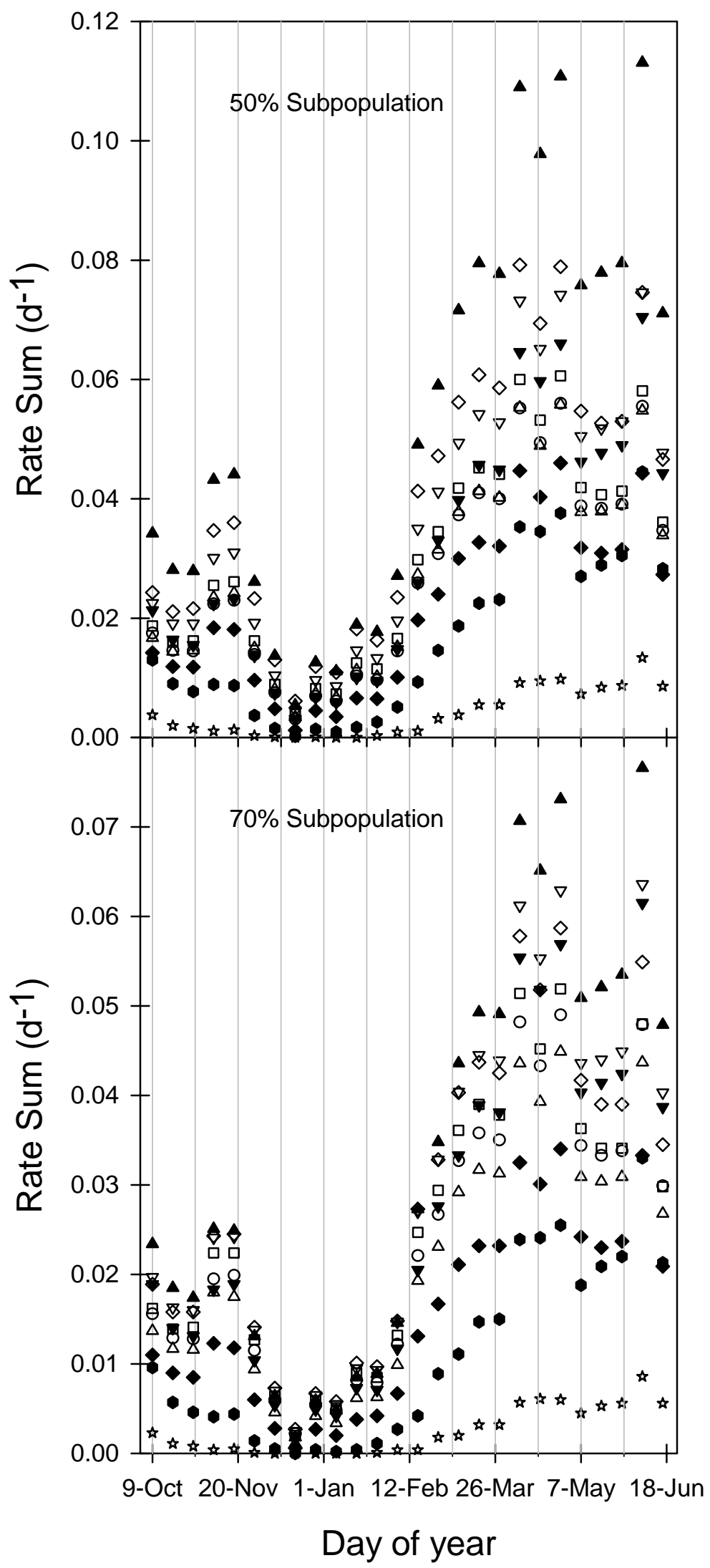

Fig. 2 


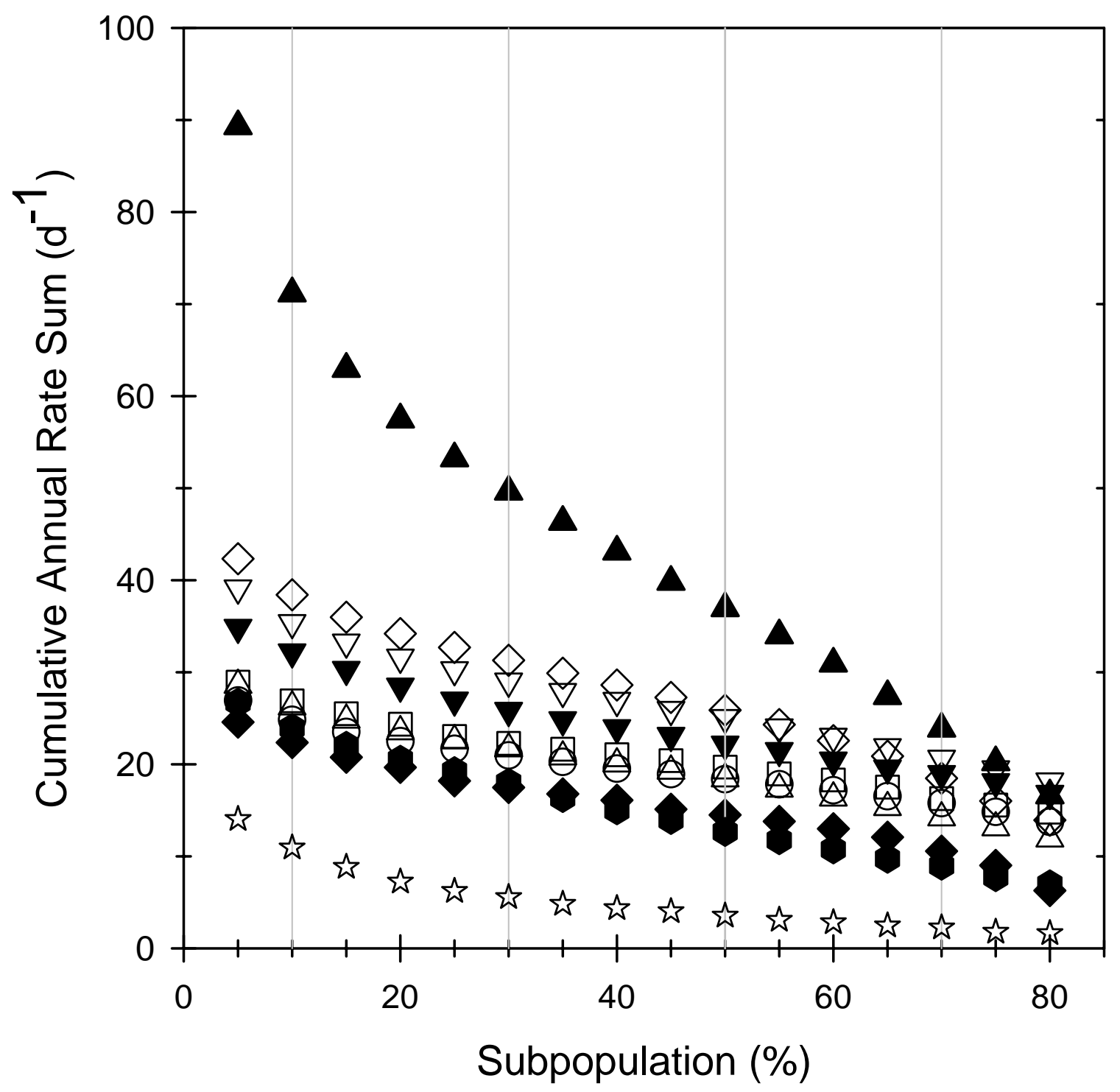

Fig.3 
A. Thermal Accumulation All Temperatures
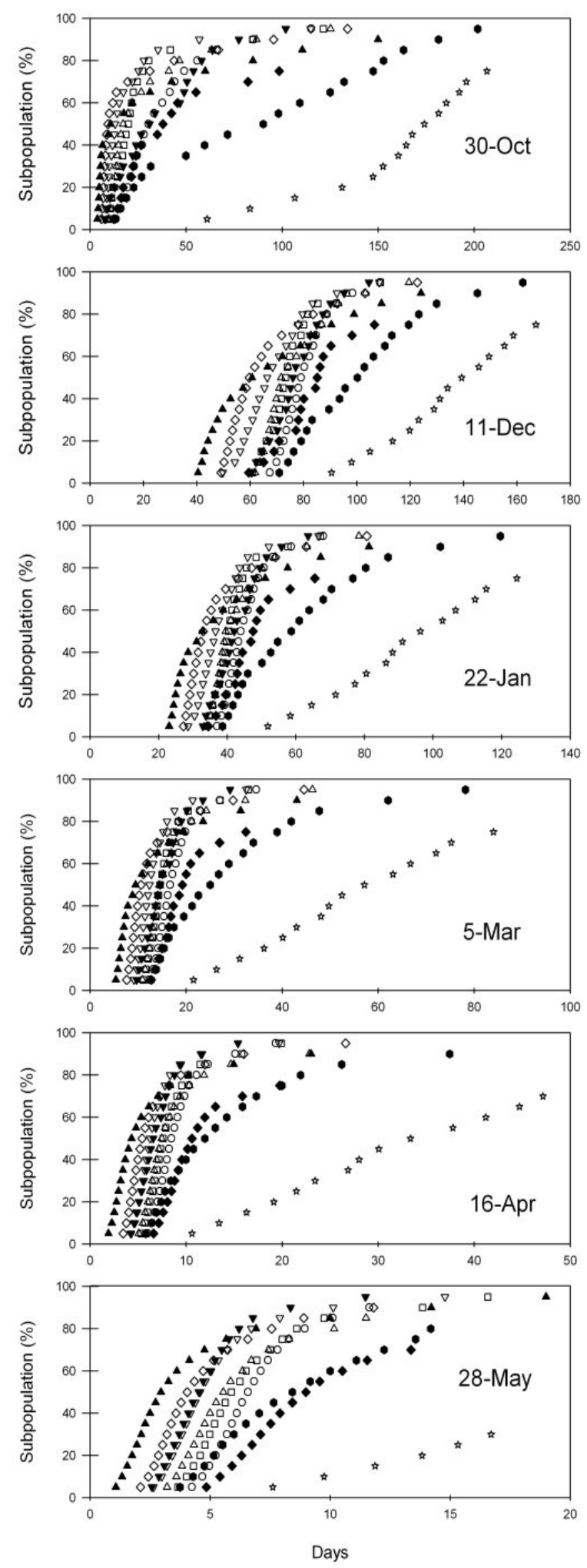

B. Thermal Accumulation above $-1.0 \mathrm{MPa}$
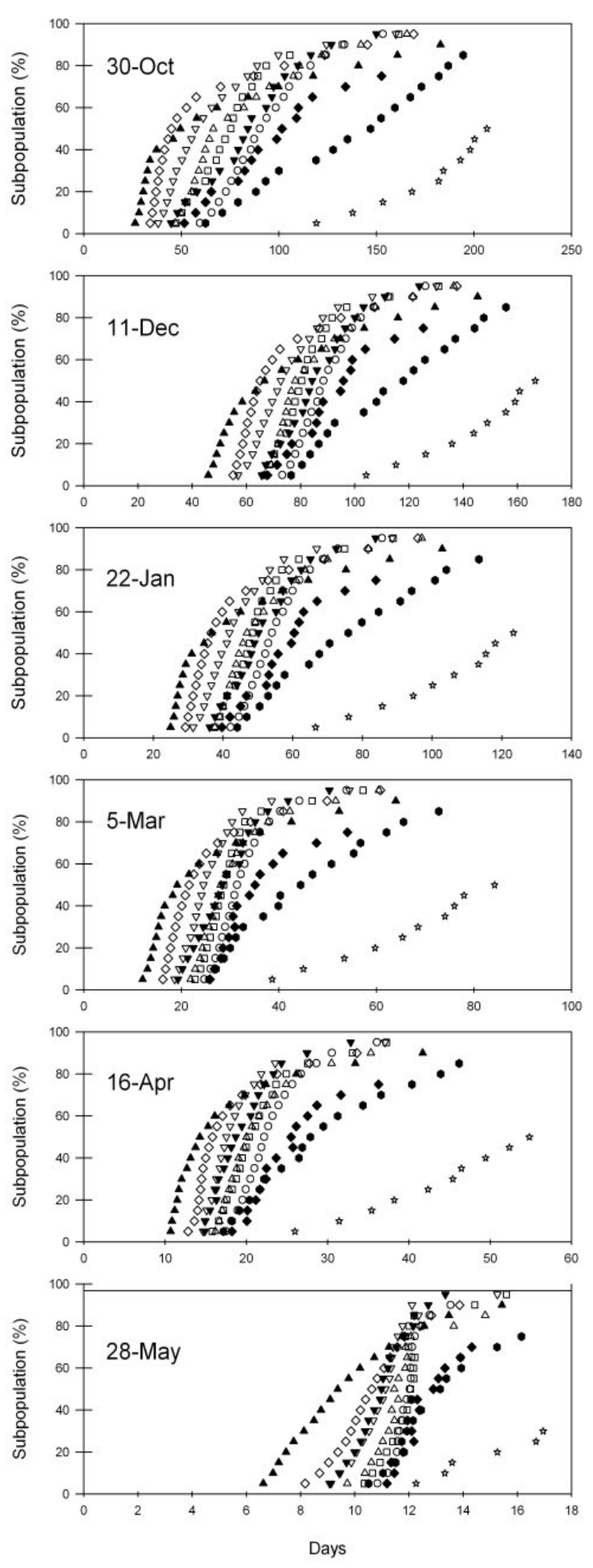

Fig. 4 